\title{
REVIEW
}

\section{Ovarian and extra-ovarian mediators in the development of polycystic ovary syndrome}

\author{
Muraly Puttabyatappa and Vasantha Padmanabhan \\ Department of Pediatrics, University of Michigan, Ann Arbor, Michigan, USA \\ Correspondence should be addressed to V Padmanabhan: vasantha@umich.edu
}

\begin{abstract}
Polycystic ovary syndrome (PCOS) is a heterogeneous endocrine disorder affecting women of reproductive age. The origin of PCOS is still not clear and appears to be a function of gene $\times$ environment interactions. This review addresses the current knowledge of the genetic and developmental contributions to the etiology of PCOS, the ovarian and extraovarian mediators of PCOS and the gaps and key challenges that need to be addressed in the diagnosis, treatment and prevention of PCOS.
\end{abstract}

\author{
Key Words \\ - polycystic ovary syndrome \\ - ovary \\ - follicle \\ - granulosa cells \\ - developmental \\ programming \\ - androgen \\ - insulin \\ sheep
}

\section{Introduction}

Polycystic ovarian syndrome (PCOS) is the most common infertility disorder affecting $5-20 \%$ of women in their reproductive age (Azziz et al. 2016). Stein and Leventhal described this condition for the first time in 1935 when they identified in seven patients enlarged ovaries in association with menstrual disturbances (most notably amenorrhea), sterility, pain or hyperandrogenism (Stein \& Leventhal 1935). Since then PCOS has been recognized as a heterogeneous condition with various consensus meetings establishing diagnostic criteria for the identification and treatment of this condition. The 1990 United States National Institutes of Health (NIH) diagnostic criteria include clinical and/or biochemical signs of hyperandrogenism and menstrual dysfunctions (Zawadzki \& Dunaif 1992), while the 2003 Rotterdam consensus requires meeting two of the following features: clinical and/or biochemical hyperandrogenism, oligo-/ an-ovulation or polycystic ovaries (The Rotterdam ESHRE/ ASRM-Sponsored PCOS Consensus Workshop Group 2004). The androgen excess society in 2006 also proposed that all features such as clinical and/or biochemical hyperandrogenism and ovarian dysfunction including oligo/anovulation and/or polycystic ovaries should be considered as diagnostic features of PCOS (Azziz et al. 2009). All these criteria, regardless of which source, required exclusion of disorders that mimic similar symptoms such as thyroid dysfunction, hyperprolactinemia, adrenal hyperplasia, androgen-secreting tumors, among others. In spite of these, confusion regarding the use of different criteria in diagnosis and research continued, which prompted NIH through its Consensus Development Programs to organize an Evidence-Based Methodology 
Table 1 Different PCOS sub-phenotypes for diagnostic criteria recommended by the expert panel at the NIH's Evidence-Based Methodology PCOS Workshop.

\begin{tabular}{|c|c|c|c|c|}
\hline \multirow[b]{2}{*}{ Symptoms } & \multicolumn{4}{|c|}{ Sub-phenotype } \\
\hline & A & $\underline{B}$ & $\underline{\mathrm{C}}$ & $\underline{D}$ \\
\hline $\begin{array}{l}\text { Clinical and biochemical signs of } \\
\text { hyperandrogenism }\end{array}$ & + & + & + & - \\
\hline Ovulatory dysfunctions & + & + & - & + \\
\hline $\begin{array}{l}\text { Polycystic ovary morphology } \\
\text { (PCOM) }\end{array}$ & + & - & + & + \\
\hline
\end{tabular}

PCOS Workshop. This workshop panel recommended adoption of the broader 2003 Rotterdam criteria with sub-classification of the PCOS sub-phenotypes as depicted in Table 1 (National Institutes of Health 2012). All in all, PCOS is a complex condition manifesting a wide variety of dysfunctions in addition to those considered as diagnostic criteria. These include (i) cardiometabolic dysfunctions such as basal and glucose-stimulated hyperinsulinemia independent of their BMI (Dunaif et al. 1989), insulin resistance (Dunaif et al. 2001, DeUgarte et al. 2005) and increased risk for cardiovascular diseases (Legro et al. 2001, Cobin 2013), ii) depression (Cooney \& Dokras 2017), (iii) gestational diabetes and pre-eclampsia and (iv) poor birth outcomes such as small or large for gestational age newborns, congenital abnormalities and perinatal mortality (Boomsma et al. 2006, Qin et al. 2013, Doherty et al. 2015). This review aims to summarize the potential causes with focus on the ovarian and extraovarian factors implicated in the pathogenesis of PCOS.

\section{Origin of PCOS}

Because of the heterogeneous nature of this condition, the etiopathology of PCOS is still not clearly identified. Factors ranging from genetic to environmental and/or the interaction between them have been proposed to have a role in the origin of PCOS.

\section{Genetic basis in the origin of PCOS}

The observations that there is a high amount of familial aggregation among first-degree female relatives of women with PCOS (Legro et al. 1998a) coupled with heritability score of 0.79 for PCOS phenotype in the Dutch twin study (Vink et al. 2006) provide credence for the notion that PCOS is heritable (Franks et al. 1997). Among the diagnostic characteristics of PCOS, evidence for heritability is strongest for hyperandrogenism (Legro et al. $1998 a, b)$. Nonetheless, considering the heterogeneity in
PCOS phenotypes and the varying attributes, it is now not believed to be a monogenic disease (Fenichel et al. 2017). In support of this, mutations or polymorphism in several genes have been identified (Dunaif 2016). Both individual gene analysis and genome-wide association studies (GWAS) have identified mutations or polymorphisms in follicle-stimulating hormone receptor (FSHR), luteinizing hormone receptor (LHCGR), DENN/MADD domain containing 1A (DENND1A), RAB5B, member RAS oncogene family $(R A B 5 B)$ and thyroid adenoma associated (THADA) gene loci in Hui Chinese and American or European Caucasian individuals with PCOS (Goodarzi et al. 2012, Eriksen et al. 2013, Louwers et al. 2013, Ha et al. 2015, Hayes et al. 2015). While mutations, polymorphisms and splice variants in genes such as follistatin, fibrilin 3, cytochrome p450 side-chain cleavage (CYP11A), insulin receptor, hydroxysteroid dehydrogenase (HSD) 17B5, HSD17B6 and androgen receptor have also been linked to PCOS, such observations have not been confirmed in large populations or in multiple ethnicities (Azziz 2016, Dunaif 2016). The degree to which each of these genes contributes to the final reproductive and metabolic phenotype of PCOS women remains unclear. For instance, while overexpression and silencing of the polymorphic variant of the DENND1A in the human theca cells, the main source of testosterone for the hyperandrogenic phenotype, has been shown to increase and decrease testosterone synthesis, respectively (McAllister et al. 2014), to what extent alterations in this is linked to other PCOS symptoms is unclear.

Genetic mouse models involving many of the gene variants linked to PCOS are limited. A transgenic mouse overexpressing the DENND1A variant identified in PCOS patients resulted in a hyperandrogenic state with no impact on fertility (Modi 2016); detailed phenotypic assessment of PCOS characteristics is not available for this model. Transgenic mouse models overexpressing LH beta subunit while manifesting chronically elevated LH/ testosterone levels and infrequent ovulation produced a cystic, tumorigenic ovarian phenotype (Risma et al. 1995). While FSH deficiency and polymorphism in FSHR has been linked to PCOS (Dolfin et al. 2011), mouse models of FSH deficiency although infertile fail to manifest a hyperandrogenic or multifollicular ovarian phenotype (Burns \& Matzuk 2002, Barnett et al. 2006). Prevention of the development of PCOS phenotype that normally follow prenatal androgen treatment in global, brain or theca cell-specific androgen receptor (AR) knock-out mice emphasizes a role for AR (Walters \& Handelsman 2017). This observation is consistent with polymorphisms in 
AR gene being linked to PCOS (Wang et al. 2015). These findings from transgenic models combined with the $<10 \%$ heritability estimate of PCOS-linked loci identified through GWAS (Azziz 2016) suggest involvement of additional loci and factors. Several transgenic models are available that link other loci (nerve growth factor, plasminogen activator inhibitor 1, estrogen receptor alpha) to PCOS characteristics (Barnett et al. 2006, Walters et al. 2012). However, these loci have not been substantiated in large PCOS cohort studies.

\section{Developmental basis in the origin of PCOS}

The observation that individuals born with low birth weight are at high risk for manifestation of cardiometabolic disorders during adulthood led to the developmental origin of health and disease hypothesis by Barker (2004). According to this hypothesis, early fetal exposure to stressors can induce physiological adaptations that fail and manifest as disease during adulthood. The findings that girls born either small or large for their gestational age are at increased risk for developing PCOS during reproductive life (Melo et al. 2010, Mumm et al. 2013), suggests PCOS could also have developmental basis. Additional support for this premise comes from reports of (1) PCOS phenotype in offspring exposed to excess androgen in utero, which occur in conditions such as congenital adrenal hyperplasia (Hague et al. 1990), congenital virilizing tumors (Barnes et al. 1994) and lossof-function mutations in aromatase (Morishima et al. 1995) or sex hormone-binding globulin gene (SHBG) (Hogeveen et al. 2002), (2) elevated second trimester amniotic fluid testosterone levels in PCOS women (Palomba et al. 2012) and (3) increased anogenital distance (Wu et al. 2017, Barrett et al. 2018) and 2nd to 4th finger (2D:4D) ratio (Palomba et al. 2012), biomarkers of prenatal androgen exposure in offspring of PCOS women. The developmental origins of PCOS theory is also supported by studies in murine, rodent, sheep and monkey models, which show that administration of steroids such as testosterone, dihydrotestosterone (DHT) or estradiol valerate or steroid synthesis inhibitors during the perinatal period induce the development of PCOS-like phenotype (Abbott et al. 2005, Padmanabhan \& VeigaLopez 2013, Maliqueo etal. 2014). For instance, the prenatal testosterone-treated female sheep, the animal model our group works with, manifests fetal growth restriction and is born with low birth weight (Manikkam et al. 2004, Steckler et al. 2005). As these animals age, they manifest disruptions in neuroendocrine steroid feedback, increased pituitary sensitivity to gonadotropin-releasing hormone, LH hypersecretion, functional hyperandrogenism, multifollicular ovarian morphology, oligo-/anovulation and insulin resistance. In addition to meeting the diagnostic criteria proposed for PCOS by all agencies, these animals manifest cardiometabolic disruptions such as that seen in women with PCOS (Padmanabhan \& Veiga-Lopez 2013, 2014s, Cardoso et al. 2015). Similarly, developmental exposure of sheep to bisphenol A (BPA, an environmental endocrine-disrupting compound (EDC) results in low birth weight (Savabieasfahani et al. 2006) offspring, which during adulthood manifest hypothalamic, pituitary and ovarian changes that mimic the PCOS phenotype (Veiga-Lopez et al. 2014a). Human studies also point to an association between BPA and hyperandrogenism (Rutkowska \& Rachon 2014).

While the findings from animal and human disease models suggest that inappropriate developmental exposure to native and environmental steroidal mimics during critical windows of differentiation can result in a PCOS phenotype, this does not necessarily imply that this is the basis for the etiology of human PCOS. For instance, although cordocentesis studies have found $40 \%$ of human female fetuses during the second trimester have male circulating levels of testosterone (Beck-Peccoz et al. 1991), the prevalence rate for PCOS is far less, only $5-20 \%$. Similarly, the prevalence of PCOS in females who are co-twin with male is not different compared to females born as part of same-sex twin pairs or singletons (Kuijper et al. 2009). These observations are at odds with the premise that developmental exposure to excess steroids, by itself, can explain the etiology of PCOS.

\section{Gene-environment interaction}

The evidence accumulated so far suggests that the pathogenesis of PCOS is likely complex and quite possibly involve gene $\times$ environment interaction. Such an interaction would not only explain the prevalence estimate of PCOS (5-20\%) relative to number of fetuses getting exposed to excess testosterone (40\%), but also the differing phenotypic manifestation of PCOS phenotypes. Phenotypic differences in neuroendocrine, ovarian and metabolic defects in animal models following prenatal androgen excess can originate from differences in the timing, duration and degree of exposure. However, the fact that phenotypic differences are also evident among animals subjected to identical exposure paradigms highlights contribution from individual genetic susceptibility to such developmental insults. Such gene $x$ environment 
interactions are likely mediated by epigenetic mechanisms (Barros \& Offenbacher 2009), involving changes in DNA methylation, histone acetylation and non-coding RNA expression (Amaral \& Mattick 2008, Kim et al. 2009). As such the epigenome provides a means to translate the information captured from the environment to heritable changes by turning on or off gene expression patterns.

From a PCOS perspective, epigenetic changes in the AR gene (Hickey et al. 2006) and increased presence of markers of epigenomic alterations in the whole blood, ovarian and adipose tissues from PCOS women have been reported (Jones et al. 2015, Li et al. 2016). Epigenetic modifications have also been observed in prenatal androgenized animal models of PCOS. These include changes in 163 and 325 methylated loci in infant and adult visceral adipose tissues of prenatally androgenized rhesus macaques ( $\mathrm{Xu}$ et al. 2011), changes in expression of miR-497 and miR-15b in fetal ovaries from prenatal testosterone-treated sheep (Luense et al. 2011) and hypomethylation of five $\mathrm{CpG}$ sites of $\mathrm{AR}$ and one single CpG site in Cyp11a1 (CpG +953) in ovaries of prenatal testosterone-treated rats (Xia et al. 2015). In this context, it is important to recognize that sex hormones (estrogens and androgens), which are perturbed in PCOS women, are known activators of epigenetic mechanisms (Crews et al. 2014, Hunter et al. 2015).

\section{Severity of PCOS phenotype}

While genetic and developmental insults induce disruptions early in life, various postnatal events such as diet, lifestyle, disease states, stress and environmental exposures can have continuing influence on the disease state. Recently, the idea that these postnatal factors may act as 'second hit' to maintain, unmask or amplify the severity of disease phenotype programmed by genetic or developmental is gaining prominence. Such a phenomenon has been described in the pathogenesis of schizophrenia and cancer (Bayer et al. 1999, Tang \& Ho 2007). Because PCOS symptoms do not become apparent till puberty, postnatal factors can serve as a second hit in terms of the manifestation or amplification of the severity of the PCOS phenotype. For instance, LH excess and metabolic disruptions that originate from the disruption of the fetal hypothalamic-pituitary-ovarian axis by the maternal hyperandrogenic condition (first hit) themselves can serve as a second hit contributing to the severity of offspring's reproductive and metabolic phenotype (Bremer 2010). Additionally, 38-88\% of PCOS patients have obesity with associated metabolic disorders such as insulin resistance (Diamanti-Kandarakis \& Dunaif 2012) and hyperinsulinemia due to insulin resistance can act as a second hit. Hyperinsulinemia increases theca cell androgen production (Nahum et al. 1995), which when associated with reduced levels of SHBG - a buffer to sequester free testosterone, can induce hyperandrogenemia (Nestler et al. 1991). Studies in animal models provide support for the two hit hypothesis in PCOS pathogenesis. In the prenatal testosterone-treated sheep model of PCOS phenotype, postnatal obesity has been found to act as a second hit to increase the severity of PCOS-like symptoms (Steckler et al. 2009). Although not tested, PCOS phenotype has also been postulated to involve both the prenatal testosterone exposure and postnatal adiposity in rhesus macaques (Abbott et al. 1998).

\section{Mediators of PCOS}

PCOS patients manifest disruptions at both ovarian and extra-ovarian levels. Ovarian changes that contribute to the diagnostic criteria of PCOS include multifollicular appearance, hyperandrogenism, oligo/anovulation and luteal defects. The extra-ovarian changes, although not part of diagnostic criteria, include LH hypersecretion with increased LH/FSH ratio at the neuroendocrine level and hyperinsulinemia, hyperglycemia, dyslipidemia and altered adipokine secretion at the metabolic level. The ovarian and extra-ovarian factors that contribute toward the phenotypic manifestation of PCOS are discussed in detail below.

\section{Ovarian mediators of PCOS}

Women with PCOS are characterized by multifollicular ovarian morphology and ovarian enlargement (an increase in ovarian area and volume). Polycystic (multifollicular) ovarian morphology (PCOM) is a criterion for the diagnosis of PCOS as defined by the 2003 Rotterdam consensus and the 2006 Androgen Excess and PCOS Society criteria and recent NIH consensus meeting (Dewailly et al. 2014, Azziz et al. 2016). Earlier ovarian studies in humans were confined to wedge resection or postmortem tissues and these studies have shown that the polycystic ovary (PCO, a misnomer terminology) appearance results from presence of $10-12$ growing follicles that measure $<10 \mathrm{~mm}$ in size along with increase in stromal hypertrophy (Hughesdon 1982). With advance in non-invasive imaging tools such as transvaginal ultrasound, follicle count thresholds for distinguishing PCOM ovaries from normal ovaries have changed over time. The most recent recommendation by 
the task force of the Androgen Excess and the Polycystic Ovary Syndrome Society (AE-PCOS) is a threshold setting of $>25$ follicles, when scanned with transducer frequency $\geq 8 \mathrm{MHz}$ (Dewailly et al. 2014).

Most studies addressing follicular number and distribution have involved single time point scanning or histological observations with postmortem ovaries. These studies have concluded ovaries of PCOS women are characterized not only by increased number of antral follicles (Dewailly et al. 2014), but also a reduction in number of primordial follicles (Webber et al. 2003) and follicular arrest (Franks et al. 2008). The PCOM phenotype in PCOS women can therefore arise from (1) enhanced recruitment and (2) follicular persistence due to arrest in follicular development, premature luteinization and reduced state of atresia (Franks et al. 2008). Additionally, women with PCOS undergoing in vitro fertilization have been found to produce more number of oocytes, which are often of poor quality thus contributing to the reduced fertilization, cleavage and implantation rates (Qiao \& Feng 2011). The potential ovarian mediators of each of these aspects of ovarian disruptions are discussed below and summarized in Table 2.

\section{Follicular activation/recruitment}

Ovaries have finite number of primordial follicles at birth that form the ovarian follicular pool or reserve where they remain in a quiescent state. The transition of quiescent primordial follicles in the ovary to primary follicles that initiates the growing phase is referred to as follicular activation or recruitment (Fig. 1). During each reproductive cycle, a few follicles from the primordial pool undergo activation/recruitment, of which only a few undergo further follicular development into preantral follicles with others undergoing atresia through programmed cell death (Pru \& Tilly 2001). The follicular activation process is tightly controlled by paracrine and autocrine factors such as transforming growth factor (TGF) family members TGF $\alpha$, TGF $\beta$, bone morphogenetic protein 4 (BMP4) and anti-Mullerian hormone (AMH), growth factors or cytokines such as kit ligand (KITL), fibroblast growth factor (FGF) and leukemia inhibitory factor (LIF) and steroid hormones (Skinner 2005). These growth factors either activate (KITL, FGF, TGF $\alpha$, LIF and $\mathrm{BMP} 4$ ) or inhibit (AMH and TGF $\beta$ ) the activation process so the balance between them likely determine the direction of the activation process (Gougeon 2010). Additionally, presence of factors that regulate the bioavailability of these growth factors, for example, fibrillins that sequester TGF family members (Bastian et al. 2016), can also govern the follicular activation process. Genetic studies showing increased follicular activation in protein kinase B (AKT) inhibitor, phosphatase and tensin homolog (Pten) (Reddy et al. 2008) and AKT-dependent transcription factor forkhead box O3a (Foxo3a) (Castrillon et al. 2003) knockout mouse have shed light on these cell signaling pathways. Androgens can also induce follicular activation via stimulation of AKT signaling and inhibition of FOXO3A protein (Lebbe \& Woodruff 2013). In addition, anti-apoptotic proteins such as B-cell lymphoma-2 (BCL2) promote follicular survival and increase the rate of activation, while pro-apoptotic proteins such as BCL2associated $\mathrm{X}$ protein (BAX) decrease the rate of activation by increasing follicular atresia (Hussein 2005).

The suggestion of increased follicular recruitment in PCOS came from initial histological studies by Hughesdon (Hughesdon 1982) and later confirmed by others (Webber et al. 2003, Maciel et al. 2004), which indicated that ovaries from PCOS women have increased number of primary follicles. Although the reason for such increase is still not clear, the identification that one of the PCOS susceptibility locus D19S884 allele 8 that maps to
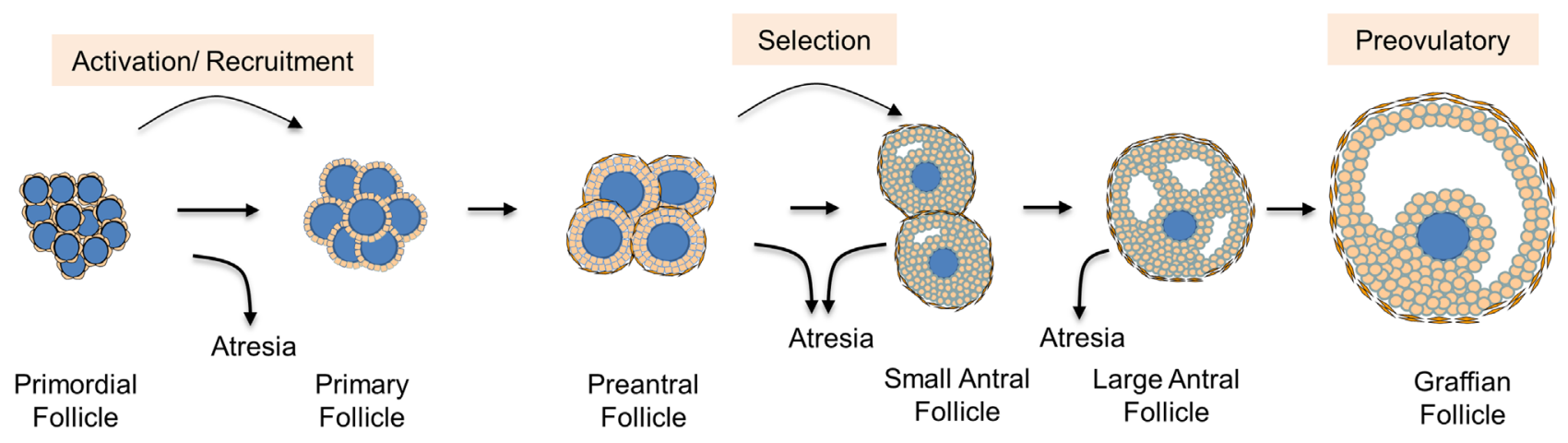

Figure 1

Schematic showing the stages of follicular development in normal ovary. 
Table 2 Ovarian factors that contribute to PCOS phenotype.

\begin{tabular}{|c|c|c|c|}
\hline Factor & Changes observed in PCOS patients (references) & Ovary-specific mechanisms & Role \\
\hline \multicolumn{4}{|c|}{ Follicular activation/recruitment } \\
\hline $\mathrm{AMH}$ & $\begin{array}{l}\text { Low AMH expression in primordial and transitional } \\
\text { follicles (Stubbs et al. 2005) }\end{array}$ & Inhibits follicular activation & Inhibits activation \\
\hline FBN3 & $\begin{array}{l}\text { Polymorphisms in D19S884 allele } 8 \text { that maps to } \\
\text { fibrillin } 3 \text { (FBN3) gene (Urbanek et al. 1999) }\end{array}$ & $\begin{array}{l}\text { Regulates bioavailability of TGF } \\
\text { family members }\end{array}$ & $\begin{array}{l}\text { May contribute } \\
\text { to activation of } \\
\text { follicles }\end{array}$ \\
\hline Androgens & $\begin{array}{l}\text { General and ovarian hyperandrogenism (reviewed } \\
\text { in Franks et al. 2008, Dewailly et al. 2016) }\end{array}$ & $\begin{array}{l}\text { Stimulates AKT pathway that } \\
\text { leads to inactivation of FOXO3 }\end{array}$ & $\begin{array}{l}\text { Increases } \\
\text { activation }\end{array}$ \\
\hline \multicolumn{4}{|c|}{ Follicular persistence/arrest } \\
\hline Androgens & $\begin{array}{l}\text { General and ovarian hyperandrogenism (reviewed } \\
\text { in Dewailly et al. 2016) }\end{array}$ & $\begin{array}{l}\text { Contributes to increase FSHR and } \\
\text { LHR expression that leads to } \\
\text { induction of premature } \\
\text { luteinization }\end{array}$ & Causes arrest \\
\hline Estrogens & $\begin{array}{l}\text { Increased or low follicular fluid levels (reviewed in } \\
\text { Franks et al. 2008) }\end{array}$ & $\begin{array}{l}\text { Increased levels reduce pituitary } \\
\text { FSH secretion and low levels can } \\
\text { inhibit follicular growth }\end{array}$ & $\begin{array}{l}\text { Contributes to } \\
\text { arrest }\end{array}$ \\
\hline Activin & $\begin{array}{l}\text { Decreased follicular fluid and serum levels (Norman } \\
\text { et al. 2001) }\end{array}$ & $\begin{array}{l}\text { Promotes pituitary FSH secretion } \\
\text { and ovarian FSH action }\end{array}$ & Prevents arrest \\
\hline Follistatin & $\begin{array}{l}\text { Increased follicular fluid and serum levels (Erickson } \\
\text { et al. 1995) }\end{array}$ & Inhibits activin & $\begin{array}{l}\text { Contributes to } \\
\text { arrest }\end{array}$ \\
\hline Inhibin & $\begin{array}{l}\text { Decreased inhibin A and B forms in follicular fluid } \\
\text { levels; inhibits activins (Magoffin \& Jakimiuk 1998, } \\
\text { Welt et al. 2005) }\end{array}$ & Decreases pituitary FSH secretion & Causes arrest \\
\hline $\mathrm{AMH}$ & $\begin{array}{l}\text { Increased antral follicular fluid levels (Fallat et al. 1997, } \\
\text { Desforges-Bullet et al. 2010) }\end{array}$ & Reduces sensitivity to FSH & Causes arrest \\
\hline IGF & Increased follicular fluid levels (Eden et al. 1990) & $\begin{array}{l}\text { In excess levels may inhibit } \\
\text { follicular growth }\end{array}$ & $\begin{array}{l}\text { Contributes to } \\
\text { arrest }\end{array}$ \\
\hline IGFBP & $\begin{array}{l}\text { Decreased IGFBP1 and } 4 \text { follicular fluid levels (Holly } \\
\text { et al. 1990, Cataldo \& Giudice 1992) }\end{array}$ & Regulates IGF bioavailability & $\begin{array}{l}\text { Contributes to } \\
\text { arrest }\end{array}$ \\
\hline EGF & Increased follicular fluid levels (Volpe et al. 1991) & Induces premature luteinization & Causes arrest \\
\hline NGF & High levels in follicular fluid (Dissen et al. 2009) & Unknown & Causes arrest \\
\hline VEGF & $\begin{array}{l}\text { High levels in follicular fluid } \\
\text { Increased granulosa cell and reduced theca cell } \\
\text { protein content (Savchev et al. 2010, Ferrara et al. } \\
2003 \text { ) }\end{array}$ & Induces premature luteinization & Causes arrest \\
\hline EB-VEGF & $\begin{array}{l}\text { Increased expression in stromal theca-interna cells } \\
\text { (Ferrara et al. 2003) }\end{array}$ & Promotes VEGF expression & $\begin{array}{l}\text { Contributes to } \\
\text { arrest }\end{array}$ \\
\hline FGF & $\begin{array}{l}\text { Low levels in follicular fluid levels (Hammadeh et al. } \\
\text { 2003) } \\
\text { Elevated levels in follicular fluid (Artini et al. 2006) }\end{array}$ & Induces premature luteinization & Causes arrest \\
\hline Adiponectin & $\begin{array}{l}\text { Low levels of high molecular weight form in } \\
\text { follicular fluid; decreased adiponectin and its } \\
\text { receptor expression in granulosa cells. (Artimani } \\
\text { et al. 2016) }\end{array}$ & $\begin{array}{l}\text { Promotes theca cell androgen } \\
\text { synthesis }\end{array}$ & Causes arrest \\
\hline TNF & High in follicular fluid (Amato et al. 2003) & $\begin{array}{l}\text { Participates in granulosa cell } \\
\text { differentiation, proliferation } \\
\text { and apoptosis }\end{array}$ & $\begin{array}{l}\text { Contributes to } \\
\text { arrest }\end{array}$ \\
\hline IL & $\begin{array}{l}\text { High follicular fluid IL6 and } 13 \text { and low follicular } \\
\text { fluid IL12 (Amato et al. 2003) }\end{array}$ & Reduces estradiol synthesis & $\begin{array}{l}\text { Contributes to } \\
\text { arrest }\end{array}$ \\
\hline MMP & $\begin{array}{l}\text { No change in MMP2 and } 9 \text { activities in follicular fluid } \\
\text { (Lahav-Baratz et al. 2003); higher follicular fluid } \\
\text { content of MMP2 and } 9 \text { and increased expression } \\
\text { of MMP9 in granulosa cells (Shalev et al. 2001) }\end{array}$ & Induces premature luteinization & $\begin{array}{l}\text { Contributes to } \\
\text { arrest }\end{array}$ \\
\hline TIMP & $\begin{array}{l}\text { Low TIMP1 levels in follicular fluid (Lahav-Baratz } \\
\text { et al. 2003); no change in expression in } \\
\text { granulosa cells (Shalev et al. 2001) }\end{array}$ & Regulates MMP function & $\begin{array}{l}\text { Contributes to } \\
\text { arrest }\end{array}$ \\
\hline
\end{tabular}


Table 2 Continued.

Factor

MicroRNAs

\section{FOXO3}

\section{Oocyte quality}

GDF9

BMP15

BDNF

FGF

EGF

IGF

VEGF

$\mathrm{AMH}$

IL

LIF

TNF

CRF

Changes observed in PCOS patients (references)
Decreased serum and follicular fluid levels of
soluble Fas

Promotes apoptosis (Onalan et al. 2005)

miR-320a down-regulated in cumulus cells - targets RUNX2 which regulates steroidogenesis and granulosa cell differentiation (Zhang et al. 2017)

miR-483 down-regulated in ovarian

cortex - targets IGF1 (Xiang et al. 2016)

miR-145 down-regulated in granulosa cells - targets

insulin receptor substrate 1 (IRS1) that regulates granulosa cell proliferation (Cai et al. 2017)

Decreased follicular fluid levels of miR-93 and miR-21 - targets TGF beta family members (Naji et al. 2017)

miRNAs 200a-3p, 10b-3p, 200b-3p, 29c-3p, 99a-3p, and $125 a-5 p$ are elevated and miR-105-3p is decreased in follicular fluid - many of these are associated with androgen synthesis (Xue et al. 2017) Decreased miR-145 and miR-182 in granulosa cells and increased miR-182 in follicular fluid (Naji et al. 2018)

Frizzled 3 expression increased in cumulus cells (Qaio et al. 2017)

Increased FOXO3 mRNA and protein and decreased phospho $\mathrm{FOXO} 3$ in granulosa cells from antral follicles (Mikaeili et al. 2016)

Reduced cumulus cells and normal oocyte expression of mRNA (Zhao et al. 2010)

No change in oocyte or cumulus expression of mRNA (Zhao et al. 2010)

Increased follicular fluid levels (Johnstone et al. 2008)

Low levels in follicular fluid levels (Hammadeh et al. Unknown 2003)

Elevated levels in follicular fluid (Artini et al. 2006) Increased follicular fluid levels (Volpe et al. 1991)

Increased follicular fluid levels (Eden et al. 1990)

High levels in follicular fluid (Savchev et al. 2010)

Increased antral follicular fluid levels (Fallat et al. 1997, Desforges-Bullet et al. 2010)

High follicular fluid IL6 and 13 and low follicular fluid IL12 (Amato et al. 2003)

Low follicular fluid levels (Ledee-Bataille et al. 2001)

High follicular fluid (Amato et al. 2003)

Low follicular fluid levels (Mastorakos et al. 1994)

\begin{tabular}{l} 
Ovary-specific mechanisms \\
\hline Reduced levels decrease atresia
\end{tabular}

Role

Contributes to arrest

Variable mechanism depending on their gene targets

Variable outcomes depending on their gene targets

Decreases estradiol synthesis

Promotes apoptosis of granulosa cells, participates in follicular atresia

Participates in oocyte maturation

Participates in oocyte maturation

Unknown

Involved in oocyte maturation

May be involved in oocyte maturation

Stimulates maturation of oocytes

May participate in oocyte maturation

May participate in oocyte maturation

Promotes oocyte maturation

Decreases oocyte maturation and induces abnormal chromosomal alignment and cytoskeleton structure in oocyte Unknown
Causes arrest

Causes follicular persistence

Promotes oocyte quality

Promotes oocyte quality

Promotes oocyte quality

Reduces oocyte quality

May promote oocyte quality

May promote oocyte quality Promotes oocyte quality

Reduces oocyte quality

Reduces oocyte quality

Promotes oocyte quality

Reduces oocyte quality

Promotes oocyte quality

$A M H$, anti-Mullerian hormone; FBN3, fibrillin; IGF, insulin-like frowth factor; IGFBP, IGF binding proteins; EGF, epidermal growth factor; NGF, nerve growth factor; VEGF, vascular endothelial growth factor; EB-VEGF, endocrine-gland derived VEGB; FGF, fibroblast growth factor; TNF, tumor necrosis factor alpha; IL, interleukins; MMP, matrix metalloproteinase; TIMP, tissue inhibitors of MMP; FOXO3, forkhead box O3 transcription factor; GDF9, growth diferentiation factor 9; BMP15, bone morphogenetic protein 15; BDNF, Brain-derived neurotropic factor; LIF, Leukemia inhibiting factor; CRF, Corticotrophin-releasing hormones. 
fibrillin 3 (FBN3) gene (Urbanek et al. 1999) sheds some light on ovarian factors involved during early follicular development. Considering that (1) the expression of $F B N 3$ is restricted to perifollicular stromal area of the follicles transitioning from primordial to primary stage (Jordan et al. 2010), (2) its expression is highest in the first trimester fetal ovaries (Hatzirodos et al. 2011) and (3) fibrillins can sequester TGFs (Bastian et al. 2016), FBN3 has the potential to alter the follicular developmental trajectory by altering bioavailability of TGF members. In addition, lower expression of $A M H$ in primordial and primordial to primary transitional follicles in ovaries from PCOS women compared with normal women (Stubbs et al. 2005) coupled with findings of increased follicular activation evidenced in Amh null mouse (Durlinger et al. 1999), and the ability of AMH to inhibit the number of early growing follicles from mouse ovaries cultured in vitro (Durlinger et al. 1999) indicate lower AMH expression to be conducive to follicular activation in the PCOS ovary. As such, the lower number of atretic early growing follicles in PCOS ovarian tissue (Webber et al. 2007) in the face of low AMH levels could promote follicular activation/ recruitment and survival thus increasing the cohort of early growing follicles available for further differentiation (Fig. 2) (Franks et al. 2008).

Support for enhanced recruitment also comes from prenatal testosterone-treated Suffolk (Steckler et al. 2005, Smith et al. 2009) and Poll Dorset (Forsdike et al. 2007) sheep models of PCOS, which manifest reduced primordial follicles with corresponding increase in growing follicles. In addition to this morphological evidence, (1) reduced number of early growing follicles staining positively for the follicular activation inhibitor, AMH, in ovaries from both of these prenatal testosterone-treated sheep breeds (Bull et al. 2004, Veiga-Lopez et al. 2012), (2) increased presence of AR protein in the fetal granulosa and stromal cells of the prenatal testosterone-treated Suffolk sheep (Ortega et al. 2009) indicative of increased androgen signaling and (3) reduced expression of pro-apoptotic protein BAX in granulosa cells of fetal primordial and primary follicles (Salvetti et al. 2012) are all supportive of increased follicular activation (Fig. 2). All in all, studies with sheep models of PCOS phenotype, as is the case with human PCOS provide support for involvement of paracrine factors and apoptotic machinery in increasing follicular recruitment.

\section{Follicular persistence}

The activated primary follicles differentiate and grow to become preantral follicles. In vitro studies in nonhuman primates have found that AMH supports preantral

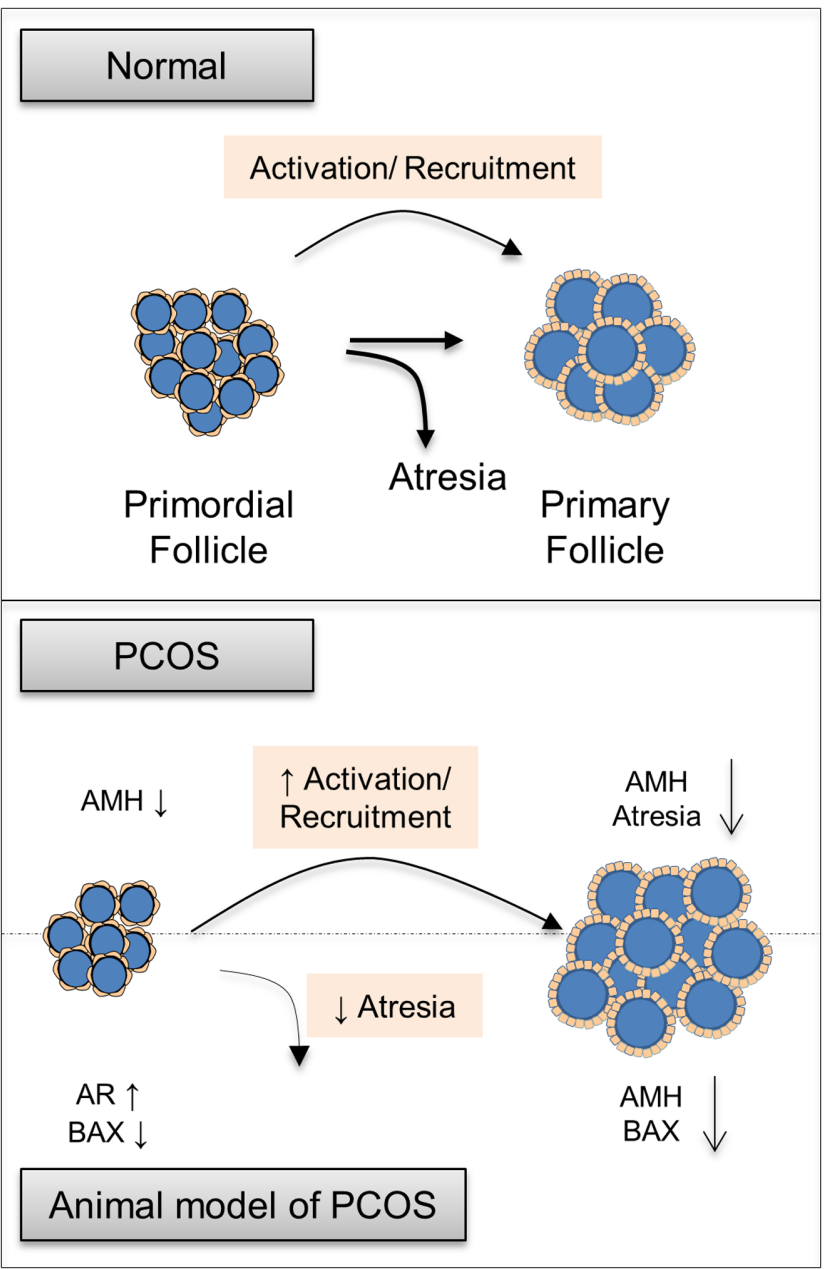

Figure 2

Schematic showing directionality of changes in factors contributing to disruptions in the follicular activation/recruitment in PCOS women and animal models of PCOS.

follicular growth (Xu et al. 2018). As such, AMH appears to have opposing effects on primordial and preantral follicles, namely one of inhibition on primordial to primary transition but stimulation on survival and growth of preantral follicles. Preantral follicles continue to develop under the stimulation of FSH into antral follicles that transition through small to large antral follicle stages. The fate of antral follicles is to either undergo atresia or mature to become preovulatory follicles that ovulate in response to LH surge and luteinize (Fig. 1). As such, the persistence of small antral follicles leading to the PCOM can arise from arrest in antral follicular growth, premature luteinization and reduced rate of atresia.

(i) Arrest in antral follicular development: Because FSH is a major regulator of antral follicular development, reduction in factors that promote sensitivity of antral follicles to FSH such as activin and insulin-like growth factor (IGF) 
or increase in factors that inhibits sensitivity to FSH such as inhibins, follistatin and AMH (Mazerbourg et al. 2003, Knight et al. 2012, Visser \& Themmen 2014) or IGFbinding proteins (IGFBP) that regulate bioavailability of IGFs (Kwintkiewicz \& Giudice 2009) can arrest follicular growth. Other factors that can contribute to follicular growth arrest include epidermal growth factor (EGF), nerve growth factor (NGF) and tumor necrosis factor alpha (TNF) (Jonard \& Dewailly 2004).

Lower levels of activin (Norman et al. 2001) coupled with higher follistatin (Erickson et al. 1995) and AMH levels in follicular fluid of women with PCOS (Fallat et al. 1997, Desforges-Bullet et al. 2010) are consistent with reduced FSH sensitivity and growth arrest (Fig. 3). In addition, higher antral follicular fluid levels of EGFs (Volpe et al. 1991), NGF (Dissen et al. 2009) and TNF (Amato et al. 2003) also contribute to antral follicular growth arrest/follicular persistence. While the high levels of IGF1 found in PCOS follicles (Eden et al. 1990) are inconsistent with growth arrest, their action may have been offset by parallel increases in IGF-binding proteins (IGFBP) (Holly et al. 1990, Cataldo \& Giudice 1992).

The prenatal T-treated sheep model of PCOS, only model where serial ultrasonographic scans have been performed for over 25 days, has provided evidence in support of antral follicles surviving for longer periods (Manikkam et al. 2006, Veiga-Lopez et al. 2014b) without further growth, supportive of follicular arrest and persistence. Intra-follicular changes observed in prenatal testosterone-treated sheep namely increased follistatin and reduced activin $\beta \mathrm{B}$ mRNA levels (West et al. 2001) and increased AMH protein content in granulosa cells (Veiga-Lopez et al. 2012) and TNF in the theca cells (Puttabyatappa et al. 2017b) of antral follicles, parallel what has been observed in PCOS women. Altered steroid receptor balance with an increase in estrogen receptor alpha (ESR1) and AR and decrease in estrogen receptor beta (ESR2) protein content in granulosa cells of antral follicles (Ortega et al. 2009) leading to reduced estrogen action are consistent with impaired antral follicle growth (Volpe et al. 1991). These findings are consistent with increase in negative mediators of follicular FSH sensitivity and reduced antral follicle growth contributing to the follicular arrest in prenatal testosterone-treated sheep (Fig. 3).

(ii) Premature luteinization: The growth of the antral follicles that develop from small to large antral and preovulatory stage terminates with the follicle differentiating under the influence of ovulatory gonadotropin surge into corpus luteum through a process known as luteinization. The intra-ovarian factors that

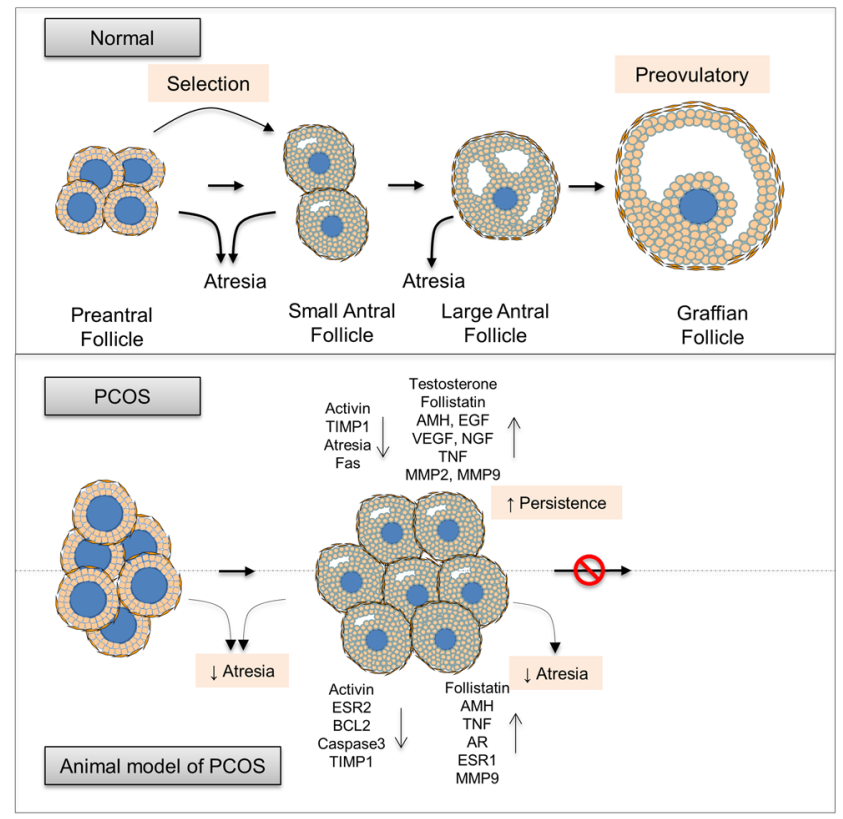

\section{Figure 3}

Schematic showing directionality of changes in factors contributing to follicular persistence in PCOS women and animal models of PCOS.

promote luteinization are androgens (Nielsen et al. 2011), adiponectin (Palin et al. 2012), proteases such as matrix metalloproteases (MMP), growth factors such as epidermal growth factors (EGF), vascular endothelial growth factors (VEGF), FGFs and cytokines such as interleukins and LIF (Giovanni Artini et al. 2007). The increases in these factors during the small antral stage can induce premature luteinization (Franks et al. 2008, Dewailly et al. 2016) thus contributing to the follicular persistence.

Thecal androgen excess (Gilling-Smith et al. 1994), premature expression of LH receptors possibly the consequence of the hyperandrogenic status (Willis et al. 1998, Dewailly et al. 2016), increased follicular fluid EGF (Volpe et al. 1991) and VEGF (Ferrara et al. 2003) and increased granulosa cell expression of $V E G F$ and endocrine gland-derived VEGF (EB-VEGF) (Ferrara et al. 2003), increased MMP2 and 9 and reduced tissue inhibitor of MMPs (TIMP1) content in the follicular fluid and increased MMP9 but not TIMP1 expression in granulosa cells (Shalev et al. 2001, Lahav-Baratz et al. 2003) and increase in cytokines interleukin 6 and TNF (Amato et al. 2003) evidenced in women with PCOS are all consistent with premature luteinization and follicular persistence.

Similarly, the increases in AR (Ortega et al. 2009), VEGF and its receptor VEGFR3 (Ortega et al. 2015) and increase in MMP9 with reduction in TIMP1 and matrix proteins laminin B and collagen protein observed in antral follicles of prenatal testosterone-treated sheep (Puttabyatappa 
et al. 2017b) are consistent with premature luteinization in this animal model of PCOS.

(iii) Follicular atresia: Follicular development involves cyclical recruitment of a cohort of small antral follicles out of which one of them (in monoovulatory and several in litter-bearing species) emerge to be dominant that goes on to ovulate while the rest of them undergo atresia through apoptosis (Fig. 1) (Pru \& Tilly 2001). Increased expression of growth factors such as EGF and IGF that promote cell survival (Homburg \& Amsterdam 1998) and loss of balance between pro-apoptotic proteins such as Fas and BCL2associated $\mathrm{X}$, apoptosis regulator (BAX) and anti-apoptotic proteins such as BCL2 (Escobar et al. 2011) can disrupt the atretic process contributing to follicular persistence and accumulation leading to the PCOM phenotype.

Consistent with the decreased atresia providing a basis for accumulation of follicles leading to PCOM phenotype DNA fragmentation, soluble Fas (sFas) and soluble Fas ligand (sFasL), markers of apoptosis were lower in granulosa cells from PCOS patients (Onalan et al. 2005). As such, low follicular fluid levels of soluble Fas (Onalan et al. 2005) coupled with high levels of growth factors EGF (Volpe et al. 1991) and IGF1 (Eden et al. 1990) in PCOS patients are consistent with reduced atresia and increased follicular survival leading to persistence.

Similarly, imbalance in opposing proliferative and apoptotic signals represented as an increase in expression of the proliferative marker PCNA and decrease in BCL2 and activated caspase- 3 in granulosa cells (Salvetti et al. 2012) coupled with increased TNF in theca cells of antral follicles (Puttabyatappa et al. 2017b) in the sheep model of PCOS phenotype are also consistent with reduced atresia contributing to accumulation of antral follicles.

\section{Oocyte quality}

Ovarian folliculogenesis and oogenesis occurs in parallel with follicular somatic cells and oocytes influencing each other during the developmental process. Although oocyte meiotic arrest occurs during early stages of follicle formation, oocyte-secreted factors influence follicle growth (Eppig 2001). While the granulosa cell secretions provide nutrient support and maintain meiotic arrest till induction of ovulation (Albertini 2015), factors produced by follicular somatic cells such as EGFs (Hsieh et al. 2009), IGFs (Wang \& Sun 2007), FGFs (Artini et al. 2006), brainderived neurotropic factor (BDNF) (Kawamura et al. 2005), VEGF (Luo et al. 2002) and LIF (Ledee-Bataille et al. 2001) and oocyte-derived factors GDF9 and BMP15 (Hussein et al. 2006) are associated with good oocyte quality. Factors such as androgens (Teissier et al. 2000), AMH (Fallat et al. 1997), TNF (Ma et al. 2010) and cytokine IL6, IL12 and IL13 (Gazvani et al. 2000, Amato et al. 2003) and corticotrophin-releasing hormones (CRF) (Mastorakos et al. 1994) are associated with poor oocyte quality.

Several studies have elaborated on the poor oocyte quality of women with PCOS (Franks et al. 2003, Qiao \& Feng 2011). For instance, ovulation induction through stimulation cycles in anovulatory PCOS has been shown to produce increased number of oocytes (Qiao \& Feng 2011) but of smaller oocyte size (Marquard et al. 2011). Excess ovarian androgen (Gilling-Smith et al. 1994), and follicular fluid FGF (Artini et al. 2006), TNF, IL6 and IL13 (Amato et al. 2003) and low follicular fluid levels of LIF (Ledee-Bataille et al. 2001) and CRF (Mastorakos et al. 1994) and reduced expression of GDF9 in cumulus cells (Zhao et al. 2010) of PCOS women (Table 2) are consistent with poor oocyte quality (Qiao \& Feng 2011). On the contrary, increased follicular fluid content of EGF (Volpe et al. 1991), VEGF (Ferrara et al. 2003), IGF1 (Eden et al. 1990) and BDNF (Johnstone et al. 2008) are inconsistent with poor oocyte quality in PCOS patients. These data indicate that the balance between factors that promote oocyte quality and those that reduce quality may be shifted to the negative side in women with PCOS thus contributing to reduced oocyte competence and fertility outcomes in PCOS patients (Franks et al. 1998, Franks et al. 2003). Differential expression of genes in oocytes from PCOS women indicative of defects in meiosis or early embryonic development (Wood et al. 2007) provide further support for this premise. Additionally, fertilization rates in PCOS women in IVF settings have yielded variable results ranging from no effect to higher rates of fertilization (Sermondade et al. 2013). While the pregnancy rates among PCOS women undergoing IVF have been found to be similar to the non-PCOS women undergoing IVF (Heijnen et al. 2006), various meta-analysis have shown that infants born to women with PCOS are at higher risk for preterm birth, low birth weight, perinatal mortality, congenital abnormalities and likelihood of birth by Cesarean section (Boomsma et al. 2006, Qin et al. 2013). These findings raise concerns regarding the quality of oocytes used in IVF settings.

While the factors that regulate oocyte maturation and competency have not been well characterized in most animal models of PCOS, reduced oocyte competency have been reported in prenatally androgenized rhesus macaques (Dumesic et al. 2002). In the sheep model of PCOS, oocyte competence has not been directly examined 
but mating studies showing reduced pregnancy rate (Steckler et al. 2007) suggest poor oocyte quality may also be a contributing factor in this model. An increase in VEGF (Ortega et al. 2015), which parallel what is seen in women with PCOS (Ferrara et al. 2003), is not consistent with poor oocyte quality; however, its beneficial effect appears to be offset by the increase in granulosa cell AMH (Veiga-Lopez et al. 2012) and thecal cell TNF (Puttabyatappa et al. 2017b).

\section{Extra-ovarian mediators of PCOS}

In addition to the ovarian mediators discussed earlier, disruptions in extra-ovarian mediators (Fig. 4) such as neuroendocrine secretions from the hypothalamopituitary axis that act on the ovary to regulate ovarian steroidogenesis, follicular development, ovulation and corpus luteum formation can play an important role in the pathogenesis of PCOS. The main neuroendocrine changes observed in PCOS women are high LH and subnormal FSH levels leading to higher LH/FSH ratio, the consequence of disruptions in steroid-negative feedback mechanisms and reduced pituitary sensitivity to GnRH (Balen et al. 1993, Taylor et al. 1997, McCartney et al. 2002, Gill \& Hall 2014). In addition, metabolic factors such as insulin and adiponectin can also influence ovarian function with the former serving as a co-gonadotropin and the latter influencing sensitivity to insulin. Consistent with this, hyperinsulinemia is the main metabolic abnormality observed in majority of the patients with PCOS (DiamantiKandarakis \& Dunaif 2012) along with hyperglycemia, dyslipidemia and hypoadiponectinemia (Palin et al. 2012, Churchill et al. 2015). While ovary is the major contributor for the hyperandrogenic state, increased circulating adrenal androgen DHEAS levels present in 15-45\% in women with PCOS (Luque-Ramírez \& Escobar-Morreale 2016) indicates adrenal factors also play an important role in the development of PCOS. Further, growing evidence also point to role of other factors, such as environmental chemicals and lifestyle, in the manifestation of PCOS.

\section{Neuroendocrine mediators}

The ovarian function is tightly regulated by the integration of the HPO axis through feed-forward and negative and positive feedback loops. The hypothalamic secretion of GnRH on the pituitary and anterior pituitary secretion of FSH and LH on the ovary form the feed-forward response. The ovarian steroids androgens, estradiol and progesterone and peptide hormones such as inhibin and follistatin produced by the ovary and the pituitary provide the negative feedback loop to the hypothalamo-pituitary axis. The midcycle rise in estradiol drives the positive feedback at the level of the hypothalamus and pituitary to cause surge release of LH that triggers ovulation. Disruptions in the feed-forward and feedback mechanism will influence LH and FSH, the

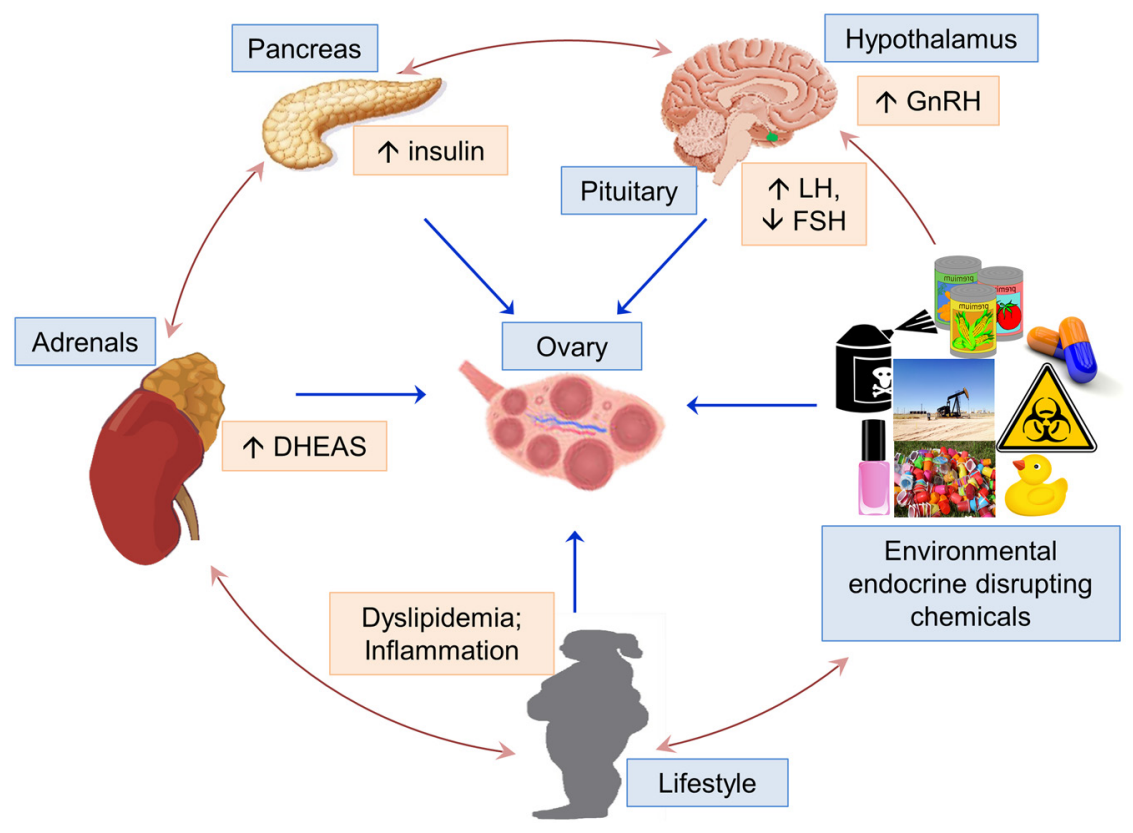

Figure 4

Schematic showing extra-ovarian factors contributing to ovarian disruptions in PCOS women and animal models of PCOS. Images used in this figure were sourced from www.pixabay.com, www.publicdomainvectors.org, commons.wikimedia.org and www.openclipart.org. 
main hypothalamo-pituitary regulators of ovary, which in turn will have a negative impact on ovarian function.

Neuroendocrine studies carried out in PCOS women provide evidence in support of abnormalities in the hypothalamic-pitutary axis contributing to the pathogenesis of PCOS. The increase in frequency of GnRH release assessed using LH as a bioassay (Pagan et al. 2006) and exaggerated LH response to exogenous GnRH (Gill \& Hall 2014) together appear to underlie the LH hypersecretion in women with PCOS. The increases in $\mathrm{GnRH} / \mathrm{LH}$ in turn appear to be a function of reduced sensitivity to steroid negative feedback (Marshall \& Eagleson 1999, Burt Solorzano et al. 2012). Findings that high concentrations of estradiol and progesterone are required to reduce pulsatile LH release (Pastor et al. 1998) and steroid sensitivity can be restored with androgen antagonist flutamide treatment (Eagleson et al. 2000) do provide evidence in support of compromised steroid negative feedback sensitivity in PCOS patients. While pituitary levels of activin and follistatin are not known, the observations that PCOS patients have low circulating levels of activin (Norman et al. 2001) and increased follicular fluid follistatin (Erickson et al. 1995) are consistent with the low FSH levels.

Analogous scenario also exists in prenatal testosterone-treated animal models (Cardoso et al. 2015, Abbott et al. 2016). For instance, consistent with disruptions in the feedback mechanisms at pituitary and hypothalamic levels, prenatal testosterone-treated sheep manifest increased pituitary sensitivity to GnRH (Manikkam et al. 2008), reduced sensitivity to estradiol negative (Wood \& Foster 1998, Sarma et al. 2005), estradiol positive (Wood \& Foster 1998, Sharma et al. 2002, Unsworth et al. 2005) and progesterone negative feedback (Robinson et al. 1999, Veiga-Lopez et al. 2009). Neuroanatomical studies support neuropeptide imbalance in the KNDy (kisspeptin, neurokinin B and dynorphin) neurons reflected as reduced inhibitory (dynorphin) and no change in stimulatory (kisspeptin) (Cheng et al. 2010) neuropeptides as a potential mediator of the decreased ability of progesterone to exert negative feedback effect on GnRH/LH secretion. Similar disruptions in estradiol and progesterone feedbacks have also been observed in prenatal testosterone-treated macaque (Abbott et al. 2016) and rodent (Moore et al. 2015) models. Furthermore, the protection from development of PCOS-like phenotype induced by prenatal DHT treatment in brain-specific AR-knockout mouse (Caldwell et al. 2017) indicates a neuroendocrine role for androgens in disrupting the HPO axis.

\section{Metabolic mediators}

Insulin is the major metabolic hormone that regulates glucose homeostasis and lipid metabolism in the body. When cell or tissue requires excess insulin to respond normally, it develops insulin resistance and as pancreatic beta cells respond with production of more insulin compensatory hyperinsulinemia develops. Hyperinsulinemia can induce hyperandrogenism by either directly stimulating ovarian androgen production (Hernandez et al. 1988) or indirectly through (1) enhancement of gonadotropin secretion from pituitary (Adashi et al. 1981), (2) intensifying gonadotropin action at the ovary (Cara \& Rosenfield 1988) or (3) increasing bioavailability of androgens through inhibition of liver sex hormone-binding globulin (SHBG) production (Nestler et al. 1991). In addition, hyperinsulinemic state together with hyperandrogenemia can increase FSH induction of LH receptor in granulosa cells of antral follicles and also LH action to induce premature luteinization (Willis et al. 1996). Hyperinsulinemia and insulin resistance evidenced in metabolic diseases are commonly associated with inflammatory state, hypoadiponectinemia and dyslipidemia, which can indirectly influence ovarian function by modulating insulin and gonadotropin action (Palin et al. 2012, Macut et al. 2013, Vassilatou 2014, Moran et al. 2015, De Leo et al. 2016).

Although $60-70 \%$ of women with PCOS are obese or overweight (Moran et al. 2015, Naderpoor et al. 2015) and obesity is associated with insulin resistance (Esser et al. 2014) the observation that majority of lean women with PCOS also manifest insulin resistance (Yildizhan et al. 2016) support a role for hyperinsulinemia in the manifestation of PCOS. The increased prevalence of chronic low-grade inflammation (Boots \& Jungheim 2015), dyslipidemia (Couto Alves et al. 2017), hypoadiponectemia (MannerasHolm et al. 2011) and NAFLD (Makri \& Tziomalos 2017) in PCOS patients, features that can negatively affect HPO axis, are also consistent with the role of metabolic factors contributing to the development of PCOS.

Similar to women with PCOS, prenatal testosteronetreated sheep also manifest reduced peripheral insulin sensitivity and hyperinsulinemia (DeHaan et al. 1990, Hansen et al. 1995, Recabarren et al. 2005, Padmanabhan et al. 2010), dyslipidemia (VeigaLopez et al. 2013, Puttabyatappa et al. 2017a) and hepatic lipid accumulation (Puttabyatappa et al. 2017a). Hyperinsulinemia with increased adiposity is also a feature of prenatal testosterone-treated macaque (Abbott et al. 1998) and rodent models (Roland et al. 2010). Hypoadiponectemia, a feature seen in women with PCOS, 
was observed in DHT-treated mouse model (Benrick et al. 2017) but not in prenatal testosterone-treated sheep (Puttabyatappa et al. 2017a).

\section{Adrenal mediators}

Although ovarian theca cell androgen production is a major source of hyperandrogenemia, adrenal production of DHEAS accounts for hyperandrogenism in about $15-45 \%$ of the women with PCOS (Luque-Ramírez \& Escobar-Morreale 2016). The presence of high DHEAS among sisters and daughters of patients with PCOS suggests that adrenal hyperandrogenism (AH) may be an inherited trait (Maliqueo et al. 2009, Yildizhan et al. 2016). The cause for $\mathrm{AH}$ among PCOS patients is either adrenal hyper-responsiveness to adrenocorticotropic hormone (ACTH) (Moran et al. 2005) or increased ACTH drive to adrenal due to reduced negative feedback stemming from decreased hyperinsulinemia-induced hepatic cortisol regeneration (Rodin et al. 1994).

Most of the data on the developmental programming of AH has come from prenatal androgen treated monkeys. Prenatally androgenized female rhesus macaques show enhanced basal and adrenocorticotropic hormone (ACTH)stimulated adrenal DHEA production suggesting adrenal defect in this model (Zhou et al. 2005). Hyperinsulinemia and increased adiposity observed in this model has been proposed as the potential mediator of $\mathrm{AH}$ (Abbott et al. 2009) and the observation that insulin sensitizer pioglitzone normalizes DHEAS response to ACTH stimulation confirms such assertions (Zhou et al. 2007).

\section{Other mediators}

In addition to ovarian and extra-ovarian mediators, other factors that can influence the ovarian function include environmental chemicals and lifestyle. Environmental cues play an important role in the regulation of ovarian function and its influence is integrated through the HPO axis (Vermeulen 1993). Environmental chemicals especially endocrine disruptors with steroid potential such as phthalates and bisphenol A (BPA) can alter the HPO functions by disrupting the steroidal feedbacks at the hypothalamus and pituitary level and steroid action at the level of the ovary (Peretz et al. 2014, Gore et al. 2015). Both under- and overnutrition, through production of stress steroids (Whirledge \& Cidlowski 2010), sex steroids (Whyte et al. 2007, Mossa et al. 2013) or metabolic factors (Duque-Guimaraes \& Ozanne 2013), can have a bearing on ovarian functions (Evans \& Anderson 2017). Lifestyle factors such as a socioeconomic status, neighborhood one lives in, stress and sedentariness can also impact the ovarian function through adverse health behavior that can lead to excessive weight gain, activation of the stress hormone axis or increased exposure to environmental chemicals (Rosmond 2005, Beydoun \& Wang 2010, Nelson et al. 2012).

The identification of environmental chemicals with steroidogenic potential such as perfluorooctanoate, polychlorinated biphenyls, pesticides, polycyclic aromatic hydrocarbons and BPA (Kandaraki et al. 2011, Vagi et al. 2014) in PCOS women raise concerns regarding risks posed by these chemicals in development of PCOS. In support of this increased level of BPA has been associated with hyperandrogenic status (Rutkowska \& Rachon 2014). Likewise, overnutrition and sedentary lifestyle likely contribute to the observation that $60-70 \%$ of women with PCOS are obese. A contributory role for nutrition is emphasized by the fact that dietary changes and weight loss ameliorates PCOS symptoms (Huber-Buchholz et al. 1999, Merkin et al. 2016).

Although these observations from prospective and retrospective studies in humans suggest a role for environmental and nutritional factors in the development of PCOS, causative role for these come from studies in animal models. For example, prenatal BPA treatment in sheep induced neuroendocrine and ovarian changes that mimic PCOS patients (Savabieasfahani et al. 2006, Veiga-Lopez et al. 2014a). Similarly, postnatal overfeeding was found to amplify the reproductive phenotype of the sheep model of PCOS, leading to anovulation (Steckler et al. 2009).

\section{Ovulatory and luteal defects}

An estimated $40 \%$ of PCOS patients manifest infertility that arise due to infrequent or absent ovulation or luteal phase deficiency (Teede et al. 2010, Boutzios et al. 2013). Majority of the anovulatory PCOS phenotype is associated with accumulation of $2-8 \mathrm{~mm}$ antral follicles that fail to undergo follicle selection and dominance but persist due to excess production of AMH or premature acquisition of $\mathrm{LH}$ receptors in the granulosa cells. Normalization of HPO axis or metabolic functions has been shown to be effective in achieving ovulation (Legro 2016). Because PCOS patients have generally high LH and low FSH, utilization of estrogen receptor antagonists or aromatase inhibitors that reduce negative feedback of the estrogens on pituitary FSH secretion or exogenous FSH supplementation aid in ovulation induction (Jayasena \& Franks 2014, 
Legro 2016). Improving metabolic functions through administration of metformin, thiazolidinediones or lifestyle improvements such as dietary change, exercise and bariatric surgery have also been shown to improve ovulation induction (Balen et al. 2016). Infertility due to luteal phase deficiency is also evident in ovulatory PCOS patients who have low levels of progesterone during early luteal phase (Joseph-Horne et al. 2002). This low progesterone levels may arise due to abnormal synthesis of progesterone by granulosa cells (Doldi et al. 1998). Because high concentrations of progesterone are required to reduce $\mathrm{LH}$ release in PCOS patients (Pastor et al. 1998) supplementation of progesterone is a therapeutic approach to help normalize LH secretion and promote implantation (Unfer et al. 2005).

In the sheep model of PCOS, similar rescue of ovarian function by exogenous gonadotropin administration (Steckler et al. 2008), cyclic progesterone supplementation (Manikkam et al. 2006) or gestational rosiglitazone (an insulin sensitizing thiazolidinedione) treatment (VeigaLopez et al. 2010) or normalization of LH hypersecretion by postnatal rosiglitazone intervention (Cardoso et al. 2016) emphasize the role played by steroidal and metabolic factors in the development and maintenance of the pathology. The specific changes in intra- and extraovarian factors that contribute to the success of these interventions on follicular selection and dominance needs further investigation.

\section{Conclusions}

As discussed above, multiple factors that impact neuroendocrine, ovarian and metabolic functions are involved in the development of PCOS phenotype. The ovarian defects associated with PCOS are impacted by various intra- and extra-ovarian factors that influence follicular developmental process at multiple steps leading to increased recruitment, failure to achieve dominance or undergo atresia resulting in antral follicular developmental arrest. Differences in these multitudes of factors among the subtypes of PCOS (Table 1) may shed light on the mediators of phenotypic differences in these sub classes. However, several challenges still exist in 1) understanding the etiology of various subtypes of PCOS and lifelong consequences of PCOS, 2) developing interventions to prevent transmission of PCOS traits, 3) identifying optimal treatment strategies, and 4) complete phenotyping of the male counterpart of PCOS.

Development of preventive and intervention strategies require complete understanding of the underlying ovarian and extra-ovarian mechanisms contributing to the development of the PCOS phenotype. While genetic studies explain only a small percentage of PCOS prevalence, disease gene mapping in a larger sample size that includes women from multiple ethnic groups to identify other loci involved in the development of PCOS are required. In terms of using animal models to probe underlying mechanisms and identifying additional ovarian and extra-ovarian factors, there is a great need to expand studies to precocial species that have similar developmental trajectory of organ systems as in humans.

In view of the potential for PCOS traits to be passed on to subsequent generations and the findings of microRNA expression (Table 2) and epigenetic changes in PCOS patients (Jones et al. 2015, Li et al. 2016) and animal models of PCOS (Luense et al. 2011, Xu et al. 2011), it is important to determine if transmission across generations involve transgenerational transmission of PCOS traits or they merely reflect repetitive multigenerational transfer of traits due to programmed manifestation of hyperandrogenism and hyperinsulinemia that serve as repetitive programmers from generation to generation. For instance, PCOS women during pregnancy manifest hyperandrogenemia and hyperinsulinemia (SirPetermann et al. 2009) that could program PCOS phenotype in the genetically-susceptible offspring. Studies in animal models also support that multi- and transgenerational transfer is possible. Studies in rodents have provided evidence of transgenerational transfer of reproductive and metabolic traits following exposure to experimental chemicals (Guerrero-Bosagna 2016). To what extent insulin sensitivity changes of prenatal testosterone-treated F1 female sheep that are evident also in the F2 female sheep offspring (Burns et al. 2016) reflect repetitive hyperandrogenic status remains to be determined. Therefore, in addition to long-term follow-up of offspring of PCOS women to determine which of the PCOS traits get passed on, studies across several generations that include careful phenotyping of each generation are required in animal models to determine the mechanisms by which traits are passed on from generation to generation.

Important are also studies targeted toward development of optimal interventions for not just therapeutic but also preventive strategies. Continued efforts to identify factors and mechanisms involved in the origin of PCOS would be of immense benefit in this regard. In humans, safe intervention strategies that improve inflammatory, oxidative stress, and dyslipidemic state and/or reduce exposure to environmental endocrine 
disrupting chemicals are needed to prevent the ovarian and extra-ovarian pathologies that contribute to the development of PCOS phenotype and improve women's reproductive health. Animal models are a great resource in this regard for assessing the effectiveness of such interventions before their implementation in patients.

An emerging area of concern is also the long-term health of the PCOS women. As they age, PCOS women have shown improvements in menstrual cyclicity (Elting et al. 2000), hyperandrogenemia and insulin resistance (Brown et al. 2011). Although perimenopausal women are found to have increased prevalence of hypertension and diabetes mellitus (Dahlgren et al. 1992), a study with small sample size found the prevalence of cardiovascular diseases did not differ between general population and women previously diagnosed with PCOS during postmenopausal period (Merz et al. 2016). Studies with larger sample size are needed to determine if women with PCOS manifest higher prevalence of chronic cardiometabolic complications such as obesity, diabetes, and cardiovascular diseases during later life and the contributing factors.

Although, PCOS is generally known as a reproductive disorder in women, the metabolic complications characteristic of PCOS women are also found in male relatives and offspring of PCOS women. The observations that male relatives of PCOS women have premature male baldness (Ferriman \& Purdie 1979) and endocrine changes such as increased dehydroepiandrosterone sulfate (DHEAS), increased AMH, low SHBG, insulin resistance and abnormal gonadotropin secretion (Cannarella et al. 2018) support a male PCOS-like phenotype. Studies in prenatal T-treated male sheep also found reduced sperm cell count (Recabarren et al. 2008) and motility as well as testicular defects (RojasGarcia et al. 2010). Therefore, detailed characterization of the male complement of PCOS phenotype is required.

In conclusion, the different phenotypes of PCOS that contributes to the heterogeneous nature of this syndrome presents challenges in understanding the disease development and treatment. Meeting these challenges through research in humans and animal models will help in developing successful strategies to not only treat but also to prevent the development of PCOS in subsequent generations.

\section{Declaration of interest}

The authors declare that there is no conflict of interest that could be perceived as prejudicing the impartiality of this review.

\section{Funding}

NIH: P01 HD044232.

\section{References}

Abbott DH, Dumesic DA, Eisner JR, Colman RJ \& Kemnitz JW 1998 Insights into the development of polycystic ovary syndrome (PCOS) from studies of prenatally androgenized female rhesus monkeys. Trends in Endocrinology and Metabolism 9 62-67. (https://doi. org/10.1016/S1043-2760(98)00019-8)

Abbott DH, Barnett DK, Bruns CM \& Dumesic DA 2005 Androgen excess fetal programming of female reproduction: a developmental aetiology for polycystic ovary syndrome? Human Reproduction Update 11 357-374. (https://doi.org/10.1093/ humupd/dmi013)

Abbott DH, Levine JE \& Dumesic DA 2016 Translational insight into polycystic ovary syndrome (PCOS) from female monkeys with PCOSlike traits. Current Pharmaceutical Design 22 5625-5633. (https://doi. org/10.2174/1381612822666160715133437)

Abbott DH, Tarantal AF \& Dumesic DA 2009 Fetal, infant, adolescent and adult phenotypes of polycystic ovary syndrome in prenatally androgenized female rhesus monkeys. American Journal of Primatology 71 776-784.

Adashi EY, Hsueh AJ \& Yen SS 1981 Insulin enhancement of luteinizing hormone and follicle-stimulating hormone release by cultured pituitary cells. Endocrinology 108 1441-1449. (https://doi. org/10.1210/endo-108-4-1441)

Albertini DF 2015 Chapter 2 - The mammalian oocyte. In Knobil and Neill's Physiology of Reproduction (Fourth Edition), pp 59-97. San Diego: Academic Press.

Amaral PP \& Mattick JS 2008 Noncoding RNA in development. Mammalian Genome 19 454-492. (https://doi.org/10.1007/s00335008-9136-7)

Amato G, Conte M, Mazziotti G, Lalli E, Vitolo G, Tucker AT, Bellastella A, Carella C \& Izzo A 2003 Serum and follicular fluid cytokines in polycystic ovary syndrome during stimulated cycles. Obstetrics and Gynecology 101 1177-1182. (https://doi.org/10.1016/ S0029-7844(03)00233-3)

Artimani T, Saidijam M, Aflatoonian R, Ashrafi M, Amiri I, Yavangi M, SoleimaniAsl S, Shabab N, Karimi J \& Mehdizadeh M 2015 Downregulation of adiponectin system in granulosa cells and low levels of HMW adiponectin in PCOS. Journal of Assisted Reproduction and Genetics 33 101-110. (https://doi.org/10.1007/ s10815-015-0620-1)

Artini PG, Monti M, Matteucci C, Valentino V, Cristello F \& Genazzani AR 2006 Vascular endothelial growth factor and basic fibroblast growth factor in polycystic ovary syndrome during controlled ovarian hyperstimulation. Gynecological Endocrinology 22 465-470. (https://doi.org/10.1080/09513590600906607)

Azziz R 2016 PCOS in 2015: new insights into the genetics of polycystic ovary syndrome. Nature Reviews Endocrinology 12 74-75. (https://doi. org/10.1038/nrendo.2015.230)

Azziz R, Carmina E, Dewailly D, Diamanti-Kandarakis E, EscobarMorreale HF, Futterweit W, Janssen OE, Legro RS, Norman RJ, Taylor AE, et al. 2009 The androgen excess and PCOS Society criteria for the polycystic ovary syndrome: the complete task force report. Fertility and Sterility 91 456-488. (https://doi.org/10.1016/j. fertnstert.2008.06.035)

Azziz R, Carmina E, Chen Z, Dunaif A, Laven JS, Legro RS, Lizneva D, Natterson-Horowtiz B, Teede HJ \& Yildiz BO 2016 Polycystic ovary syndrome. Nature Reviews Disease Primers 2 16057. (https://doi. org/10.1038/nrdp.2016.57)

Balen AH, Tan SL \& Jacobs HS 1993 Hypersecretion of luteinising hormone: a significant cause of infertility and miscarriage. British Journal of Obstetrics and Gynaecology 100 1082-1089. (https://doi. org/10.1111/j.1471-0528.1993.tb15170.x)

Balen AH, Morley LC, Misso M, Franks S, Legro RS, Wijeyaratne CN, Stener-Victorin E, Fauser BC, Norman RJ \& Teede H 2016 The management of anovulatory infertility in women with polycystic 
ovary syndrome: an analysis of the evidence to support the development of global WHO guidance. Human Reproduction Update 22 687-708. (https://doi.org/10.1093/humupd/dmw025)

Barker DJ 2004 The developmental origins of adult disease. Journal of the American College of Nutrition 23 588S-595S. (https://doi.org/10.1080/ 07315724.2004.10719428)

Barnes RB, Rosenfield RL, Ehrmann DA, Cara JF, Cuttler L, Levitsky LL \& Rosenthal IM 1994 Ovarian hyperandrogynism as a result of congenital adrenal virilizing disorders: evidence for perinatal masculinization of neuroendocrine function in women. Journal of Clinical Endocrinology and Metabolism 79 1328-1333. (https://doi. org/10.1210/jcem.79.5.7962325)

Barnett KR, Schilling C, Greenfeld CR, Tomic D \& Flaws JA 2006 Ovarian follicle development and transgenic mouse models. Human Reproduction Update 12 537-555. (https://doi.org/10.1093/humupd/ dm1022)

Barrett ES, Hoeger KM, Sathyanarayana S, Abbott DH, Redmon JB, Nguyen RHN \& Swan SH 2018 Anogenital distance in newborn daughters of women with polycystic ovary syndrome indicates fetal testosterone exposure. Journal of Developmental Origins of Health and Disease 9 307-314. (https://doi.org/10.1017/ S2040174417001118)

Barros SP \& Offenbacher S 2009 Epigenetics: connecting environment and genotype to phenotype and disease. Journal of Dental Research 88 400-408. (https://doi.org/10.1177/0022034509335868)

Bastian NA, Bayne RA, Hummitzsch K, Hatzirodos N, Bonner WM, Hartanti MD, Irving-Rodgers HF, Anderson RA \& Rodgers RJ 2016 Regulation of fibrillins and modulators of TGFbeta in fetal bovine and human ovaries. Reproduction 152 127-137. (https://doi. org/10.1530/REP-16-0172)

Bayer TA, Falkai P \& Maier W 1999 Genetic and non-genetic vulnerability factors in schizophrenia: the basis of the 'two hit hypothesis'. Journal of Psychiatric Research 33 543-548. (https://doi. org/10.1016/S0022-3956(99)00039-4)

Beck-Peccoz P, Padmanabhan V, Baggiani AM, Cortelazzi D, Buscaglia M, Medri G, Marconi AM, Pardi G \& Beitins IZ 1991 Maturation of hypothalamic-pituitary-gonadal function in normal human fetuses: circulating levels of gonadotropins, their common alpha-subunit and free testosterone, and discrepancy between immunological and biological activities of circulating follicle-stimulating hormone. Journal of Clinical Endocrinology and Metabolism 73 525-532. (https:// doi.org/10.1210/jcem-73-3-525)

Benrick A, Chanclon B, Micallef P, Wu Y, Hadi L, Shelton JM, StenerVictorin E \& Wernstedt Asterholm I 2017 Adiponectin protects against development of metabolic disturbances in a PCOS mouse model. PNAS 114 E7187-E7196. (https://doi.org/10.1073/ pnas.1708854114)

Beydoun MA \& Wang Y 2010 Pathways linking socioeconomic status to obesity through depression and lifestyle factors among young US adults. Journal of Affective Disorders 123 52-63. (https://doi. org/10.1016/j.jad.2009.09.021)

Boomsma CM, Eijkemans MJ, Hughes EG, Visser GH, Fauser BC \& Macklon NS 2006 A meta-analysis of pregnancy outcomes in women with polycystic ovary syndrome. Human Reproduction Update $\mathbf{1 2}$ 673-683. (https://doi.org/10.1093/humupd/dml036)

Boots CE \& Jungheim ES 2015 Inflammation and human ovarian follicular dynamics. Seminars in Reproductive Medicine 33 270-275. (https://doi.org/10.1055/s-0035-1554928)

Boutzios G, Karalaki M \& Zapanti E 2013 Common pathophysiological mechanisms involved in luteal phase deficiency and polycystic ovary syndrome. Impact on fertility. Endocrine 43 314-317. (https://doi. org/10.1007/s12020-012-9778-9)

Bremer AA 2010 Polycystic ovary syndrome in the pediatric population. Metabolic Syndrome and Related Disorders 8 375-394. (https://doi. org/10.1089/met.2010.0039)
Brown ZA, Louwers YV, Fong SL, Valkenburg O, Birnie E, de Jong FH, Fauser BC \& Laven JS 2011 The phenotype of polycystic ovary syndrome ameliorates with aging. Fertility and Sterility 96 1259-1265. (https://doi.org/10.1016/j.fertnstert.2011.09.002)

Bull L, Stubbs S, Birch R, Robinson J, Themmen A, Visser J, Groome N, Hardy K \& Franks S 2004 Reduced expression of anti-Mullerian hormone (AMH) protein in the androgenised sheep ovary. Endocrine Abstracts 8 OC13.

Burns KH \& Matzuk MM 2002 Minireview: genetic models for the study of gonadotropin actions. Endocrinology 143 2823-2835. (https://doi. org/10.1210/endo.143.8.8928)

Burns A, Cardoso RC, Puttabyatappa M, Herkimer C \& Padmanabhan V 2016 Developmental programming: multigenerational effects of gestational exposure to excess testosterone on insulin sensitivity in female sheep. In Abstract Endocrine Society's 98th Annual Meeting and Expo, April 1-4, 2016. Boston, MA. (https://doi.org/10.1210/ endo-meetings.2016.RE.5.SUN-160)

Burt Solorzano CM, Beller JP, Abshire MY, Collins JS, McCartney CR \& Marshall JC 2012 Neuroendocrine dysfunction in polycystic ovary syndrome. Steroids 77 332-337. (https://doi.org/10.1016/j. steroids.2011.12.007)

Cai G, Ma X, Chen B, Huang Y, Liu S, Yang H, Zou W 2017 MicroRNA-145 negatively regulates cell proliferation through targeting IRS1 in isolated ovarian granulosa cells from patients with polycystic ovary syndrome. Reproductive Science 24 902-910. (https:// doi.org/10.1177/1933719116673197)

Caldwell ASL, Edwards MC, Desai R, Jimenez M, Gilchrist RB, Handelsman DJ \& Walters KA 2017 Neuroendocrine androgen action is a key extraovarian mediator in the development of polycystic ovary syndrome. PNAS 114 E3334-E3343. (https://doi.org/10.1073/ pnas.1616467114)

Cannarella R, Condorelli RA, Mongioi LM, La Vignera S \& Calogero AE 2018 Does a male polycystic ovarian syndrome equivalent exist? Journal of Endocrinological Investigation $\mathbf{4 1}$ 49-57. (https://doi. org/10.1007/s40618-017-0728-5)

Cara JF \& Rosenfield RL 1988 Insulin-like growth factor I and insulin potentiate luteinizing hormone-induced androgen synthesis by rat ovarian thecal-interstitial cells. Endocrinology 123 733-739. (https:// doi.org/10.1210/endo-123-2-733)

Cardoso RC, Puttabyatappa M \& Padmanabhan V 2015 Steroidogenic versus metabolic programming of reproductive neuroendocrine, ovarian and metabolic dysfunctions. Neuroendocrinology 102 226-237. (https://doi.org/10.1159/000381830)

Cardoso RC, Burns A, Moeller J, Skinner DC \& Padmanabhan V 2016 Developmental programming: insulin sensitizer prevents the GnRHstimulated LH hypersecretion in a sheep model of PCOS. Endocrinology 157 4641-4653. (https://doi.org/10.1210/en.2016-1613)

Castrillon DH, Miao L, Kollipara R, Horner JW \& DePinho RA 2003 Suppression of ovarian follicle activation in mice by the transcription factor Foxo3a. Science 301 215-218. (https://doi. org/10.1126/science.1086336)

Cataldo NA \& Giudice LC 1992 Follicular fluid insulin-like growth factor binding protein profiles in polycystic ovary syndrome. Journal of Clinical Endocrinology and Metabolism 74 695-697. (https://doi. org/10.1210/jcem.74.3.1371292)

Cheng G, Coolen LM, Padmanabhan V, Goodman RL \& Lehman MN 2010 The kisspeptin/neurokinin B/dynorphin (KNDy) cell population of the arcuate nucleus: sex differences and effects of prenatal testosterone in sheep. Endocrinology 151 301-311. (https:// doi.org/10.1210/en.2009-0541)

Churchill SJ, Wang ET \& Pisarska MD 2015 Metabolic consequences of polycystic ovary syndrome. Minerva Ginecologica 67 545-555.

Cobin RH 2013 Cardiovascular and metabolic risks associated with PCOS. Internal and Emergency Medicine 8 (Supplement 1) S61-S64. (https://doi.org/10.1007/s11739-013-0924-z)
(C) 2019 Society for Endocrinology Published by Bioscientifica Ltd. Printed in Great Britain 
Cooney LG \& Dokras A 2017 Depression and anxiety in polycystic ovary syndrome: etiology and treatment. Current Psychiatry Reports 19 83. (https://doi.org/10.1007/s11920-017-0834-2)

Couto Alves A, Valcarcel B, Makinen VP, Morin-Papunen L, Sebert S, Kangas AJ, Soininen P, Das S, De Iorio M, Coin L, et al. 2017 Metabolic profiling of polycystic ovary syndrome reveals interactions with abdominal obesity. International Journal of Obesity $\mathbf{4 1}$ 1331-1340. (https://doi.org/10.1038/ijo.2017.126)

Crews D, Gillette R, Miller-Crews I, Gore AC \& Skinner MK 2014 Nature, nurture and epigenetics. Molecular and Cellular Endocrinology 398 42-52. (https://doi.org/10.1016/j.mce.2014.07.013)

Dahlgren E, Johansson S, Lindstedt G, Knutsson F, Oden A, Janson PO, Mattson LA, Crona N \& Lundberg PA 1992 Women with polycystic ovary syndrome wedge resected in 1956 to 1965: a long-term follow-up focusing on natural history and circulating hormones. Fertility and Sterility 57 505-513. (https://doi.org/10.1016/S0015-0282(16)54892-4)

De Leo V, Musacchio MC, Cappelli V, Massaro MG, Morgante G \& Petraglia F 2016 Genetic, hormonal and metabolic aspects of PCOS: an update. Reproductive Biology and Endocrinology 14 38. (https://doi. org/10.1186/s12958-016-0173-x)

DeHaan K, Berger L, Bechtel P, Kesler D, McKeith F \& Thomas D 1990 Effect of prenatal testosterone treatment on nitrogen utilization and endocrine status of ewe lambs. Journal of Animal Science $\mathbf{6 8}$ 4100-4108. (https://doi.org/10.2527/1990.68124100x)

Desforges-Bullet V, Gallo C, Lefebvre C, Pigny P, Dewailly D \& CatteauJonard S 2010 Increased anti-Mullerian hormone and decreased FSH levels in follicular fluid obtained in women with polycystic ovaries at the time of follicle puncture for in vitro fertilization. Fertility and Sterility 94 198-204. (https://doi.org/10.1016/j. fertnstert.2009.03.004)

DeUgarte CM, Bartolucci AA \& Azziz R 2005 Prevalence of insulin resistance in the polycystic ovary syndrome using the homeostasis model assessment. Fertility and Sterility 83 1454-1460. (https://doi. org/10.1016/j.fertnstert.2004.11.070)

Dewailly D, Lujan ME, Carmina E, Cedars MI, Laven J, Norman RJ \& Escobar-Morreale HF 2014 Definition and significance of polycystic ovarian morphology: a task force report from the Androgen Excess and Polycystic Ovary Syndrome Society. Human Reproduction Update 20 334-352. (https://doi.org/10.1093/humupd/dmt061)

Dewailly D, Robin G, Peigne M, Decanter C, Pigny P \& Catteau-Jonard S 2016 Interactions between androgens, FSH, anti-Mullerian hormone and estradiol during folliculogenesis in the human normal and polycystic ovary. Human Reproduction Update 22 709-724. (https:// doi.org/10.1093/humupd/dmw027)

Diamanti-Kandarakis E \& Dunaif A 2012 Insulin resistance and the polycystic ovary syndrome revisited: an update on mechanisms and implications. Endocrine Reviews 33 981-1030. (https://doi. org/10.1210/er.2011-1034)

Dissen GA, Garcia-Rudaz C, Paredes A, Mayer C, Mayerhofer A \& Ojeda SR 2009 Excessive ovarian production of nerve growth factor facilitates development of cystic ovarian morphology in mice and is a feature of polycystic ovarian syndrome in humans. Endocrinology 150 2906-2914. (https://doi.org/10.1210/en.2008-1575)

Doherty DA, Newnham JP, Bower C \& Hart R 2015 Implications of polycystic ovary syndrome for pregnancy and for the health of offspring. Obstetrics and Gynecology 125 1397-1406. (https://doi. org/10.1097/AOG.0000000000000852)

Doldi N, Gessi A, Destefani A, Calzi F \& Ferrari A 1998 Polycystic ovary syndrome: anomalies in progesterone production. Human Reproduction 13 290-293. (https://doi.org/10.1093/humrep/13.2.290)

Dolfin E, Guani B, Lussiana C, Mari C, Restagno G \& Revelli A 2011 FSH-receptor Ala307Thr polymorphism is associated to polycystic ovary syndrome and to a higher responsiveness to exogenous FSH in Italian women. Journal of Assisted Reproduction and Genetics $\mathbf{2 8}$ 925-930. (https://doi.org/10.1007/s10815-011-9619-4)
Dumesic DA, Schramm RD, Peterson E, Paprocki AM, Zhou R \& Abbott DH 2002 Impaired developmental competence of oocytes in adult prenatally androgenized female rhesus monkeys undergoing gonadotropin stimulation for in vitro fertilization. Journal of Clinical Endocrinology and Metabolism 87 1111-1119. (https://doi. org/10.1210/jcem.87.3.8287)

Dunaif A 2016 Perspectiveds in polycystic ovary syndrome: from hair to eternity. Journal of Clinical Endocrinology and Metabolism $\mathbf{1 0 1}$ 759-768. (https://doi.org/10.1210/jc.2015-3780)

Dunaif A, Segal KR, Futterweit W \& Dobrjansky A 1989 Profound peripheral insulin resistance, independent of obesity, in polycystic ovary syndrome. Diabetes 38 1165-1174. (https://doi.org/10.2337/ diab.38.9.1165)

Dunaif A, Wu X, Lee A \& Diamanti-Kandarakis E 2001 Defects in insulin receptor signaling in vivo in the polycystic ovary syndrome (PCOS). American Journal of Physiology: Endocrinology and Metabolism 281 E392-E399. (https://doi.org/10.1152/ajpendo.2001.281.2.E392)

Duque-Guimaraes DE \& Ozanne SE 2013 Nutritional programming of insulin resistance: causes and consequences. Trends in Endocrinology and Metabolism 24 525-535. (https://doi.org/10.1016/j. tem.2013.05.006)

Durlinger AL, Kramer P, Karels B, de Jong FH, Uilenbroek JT, Grootegoed JA \& Themmen AP 1999 Control of primordial follicle recruitment by anti-Mullerian hormone in the mouse ovary. Endocrinology 1405789 5796. (https://doi.org/10.1210/endo.140.12.7204)

Eagleson CA, Gingrich MB, Pastor CL, Arora TK, Burt CM, Evans WS \& Marshall JC 2000 Polycystic ovarian syndrome: evidence that flutamide restores sensitivity of the gonadotropin-releasing hormone pulse generator to inhibition by estradiol and progesterone. Journal of Clinical Endocrinology and Metabolism 85 4047-4052. (https://doi. org/10.1210/jcem.85.11.6992)

Eden JA, Jones J, Carter GD \& Alaghband-Zadeh J 1990 Follicular fluid concentrations of insulin-like growth factor 1, epidermal growth factor, transforming growth factor-alpha and sex-steroids in volume matched normal and polycystic human follicles. Clinical Endocrinology 32 395-405. (https://doi.org/10.1111/j.1365-2265.1990. tb00879.x)

Elting MW, Korsen TJ, Rekers-Mombarg LT \& Schoemaker J 2000 Women with polycystic ovary syndrome gain regular menstrual cycles when ageing. Human Reproduction 15 24-28. (https://doi. org/10.1093/humrep/15.1.24)

Eppig JJ 2001 Oocyte control of ovarian follicular development and function in mammals. Reproduction 122 829-838. (https://doi. org/10.1530/rep.0.1220829)

Erickson GF, Chung DG, Sit A, DePaolo LV, Shimasaki S \& Ling N 1995 Follistatin concentrations in follicular fluid of normal and polycystic ovaries. Human Reproduction 10 2120-2124. (https://doi.org/10.1093/ oxfordjournals.humrep.a136246)

Eriksen MB, Nielsen MF, Brusgaard K, Tan Q, Andersen MS, Glintborg D \& Gaster M 2013 Genetic alterations within the DENND1A gene in patients with polycystic ovary syndrome (PCOS). PLOS ONE 8 e77186. (https://doi.org/10.1371/journal.pone.0077186)

Escobar M, Vázquez-Nin G \& Echeverría O 2011 Follicular cells. In Cell Death in Mammalian Ovary, pp 185-200. Netherlands: Springer. (https://doi.org/10.1007/978-94-007-1134-1_12)

Esser N, Legrand-Poels S, Piette J, Scheen AJ \& Paquot N 2014 Inflammation as a link between obesity, metabolic syndrome and type 2 diabetes. Diabetes Research and Clinical Practice 105 141-150. (https://doi.org/10.1016/j.diabres.2014.04.006)

Evans MC \& Anderson GM 2017 Neuroendocrine integration of nutritional signals on reproduction. Journal of Molecular Endocrinology 58 R107-R128. (https://doi.org/10.1530/JME-16-0212)

Fallat ME, Siow Y, Marra M, Cook C \& Carrillo A 1997 Mullerianinhibiting substance in follicular fluid and serum: a comparison of patients with tubal factor infertility, polycystic ovary syndrome, and 
endometriosis. Fertility and Sterility 67 962-965. (https://doi. org/10.1016/S0015-0282(97)81417-3)

Fenichel P, Rougier C, Hieronimus S \& Chevalier N 2017 Which origin for polycystic ovaries syndrome: genetic, environmental or both? Annals of Endocrinology 78 176-185. (https://doi.org/10.1016/j. ando.2017.04.024)

Ferrara N, Frantz G, LeCouter J, Dillard-Telm L, Pham T, Draksharapu A, Giordano T \& Peale F 2003 Differential expression of the angiogenic factor genes vascular endothelial growth factor (VEGF) and endocrine gland-derived VEGF in normal and polycystic human ovaries. American Journal of Pathology 162 1881-1893. (https://doi. org/10.1016/S0002-9440(10)64322-2)

Ferriman D \& Purdie AW 1979 The inheritance of polycystic ovarian disease and a possible relationship to premature balding. Clinical Endocrinology 11 291-300. (https://doi.org/10.1111/j.1365-2265.1979. tb03077.x)

Forsdike RA, Hardy K, Bull L, Stark J, Webber LJ, Stubbs S, Robinson JE \& Franks S 2007 Disordered follicle development in ovaries of prenatally androgenized ewes. Journal of Endocrinology 192 421-428.

Franks S, Gharani N, Waterworth D, Batty S, White D, Williamson R \& McCarthy M 1997 The genetic basis of polycystic ovary syndrome. Human Reproduction 12 2641-2648. (https://doi.org/10.1093/ humrep/12.12.2641)

Franks S, Mason H, White D \& Willis D 1998 Etiology of anovulation in polycystic ovary syndrome. Steroids 63 306-307. (https://doi. org/10.1016/S0039-128X(98)00035-X)

Franks S, Roberts R \& Hardy K 2003 Gonadotrophin regimens and oocyte quality in women with polycystic ovaries. Reproductive BioMedicine Online 6 181-184. (https://doi.org/10.1016/S1472-6483(10)61708-7)

Franks S, Stark J \& Hardy K 2008 Follicle dynamics and anovulation in polycystic ovary syndrome. Human Reproduction Update 14 367-378. (https://doi.org/10.1093/humupd/dmn015)

Gazvani MR, Bates M, Vince G, Christmas S, Lewis-Jones DI \& Kingsland C 2000 Follicular fluid concentrations of interleukin-12 and interleukin-8 in IVF cycles. Fertility and Sterility 74 953-958. (https://doi.org/10.1016/S0015-0282(00)01538-7)

Gill S \& Hall JE 2014 The hypothalamic-pituitary axis in PCOS. In Polycystic Ovary Syndrome, pp 81-93. New York, NY: Springer. (https:// doi.org/10.1007/978-1-4614-8394-6_6)

Gilling-Smith C, Willis DS, Beard RW \& Franks S 1994 Hypersecretion of androstenedione by isolated thecal cells from polycystic ovaries. Journal of Clinical Endocrinology and Metabolism 79 1158-1165. (https://doi.org/10.1210/jcem.79.4.7962289)

Giovanni Artini P, Monteleone P, Parisen Toldin MR, Matteucci C, Ruggiero M, Cela V \& Genazzani AR 2007 Growth factors and folliculogenesis in polycystic ovary patients. Expert Review of Endocrinology and Metabolism 2 215-223. (https://doi. org/10.1586/17446651.2.2.215)

Goodarzi MO, Jones MR, Li X, Chua AK, Garcia OA, Chen YD, Krauss RM, Rotter JI, Ankener W, Legro RS, et al. 2012 Replication of association of DENND1A and THADA variants with polycystic ovary syndrome in European cohorts. Journal of Medical Genetics 49 90-95. (https://doi.org/10.1136/jmedgenet-2011-100427)

Gore AC, Chappell VA, Fenton SE, Flaws JA, Nadal A, Prins GS, Toppari J \& Zoeller RT 2015 EDC-2: the Endocrine Society's Second Scientific Statement on Endocrine-Disrupting Chemicals. Endocrine Reviews 36 E1-E150. (https://doi.org/10.1210/er.2015-1010)

Gougeon A 2010 Human ovarian follicular development: from activation of resting follicles to preovulatory maturation. Annals of Endocrinology 71 132-143. (https://doi.org/10.1016/j.ando.2010.02.021)

Guerrero-Bosagna C 2016 Chapter 21 - Transgenerational epigenetic inheritance: past exposures, future diseases A2 - Rosenfeld, Cheryl S. In The Epigenome and Developmental Origins of Health and Disease, pp 425-437. Boston: Academic Press. (https://doi.org/10.1016/B978-012-801383-0.00021-9)
Ha L, Shi Y, Zhao J, Li T \& Chen ZJ 2015 Association study between polycystic ovarian syndrome and the susceptibility genes polymorphisms in Hui Chinese women. PLOS ONE 10 e0126505. (https://doi.org/10.1371/journal.pone.0126505)

Hague WM, Adams J, Rodda C, Brook CG, de Bruyn R, Grant DB \& Jacobs HS 1990 The prevalence of polycystic ovaries in patients with congenital adrenal hyperplasia and their close relatives. Clinical Endocrinology 33 501-510. (https://doi.org/10.1111/j.1365-2265.1990. tb03887.x)

Hammadeh ME, Fischer-Hammadeh C, Hoffmeister H, Huebner U, Georg T, Rosenbaum P \& Schmidt W 2003 Fibroblast growth factor (FGF), intracellular adhesion molecule (sICAM-1) level in serum and follicular fluid of infertile women with polycystic ovarian syndrome, endometriosis and tubal damage, and their effect on ICSI outcome. American Journal of Reproduction \& Immunology 50 124-130.

Hansen L, Drackley J, Berger L \& Grum D 1995 Prenatal androgenization of lambs: I. Alterations of growth, carcass characteristics, and metabolites in blood. Journal of Animal Science 73 1694-1700. (https://doi.org/10.2527/1995.7361694x)

Hatzirodos N, Bayne RA, Irving-Rodgers HF, Hummitzsch K, Sabatier L, Lee S, Bonner W, Gibson MA, Rainey WE, Carr BR, et al. 2011 Linkage of regulators of TGF-beta activity in the fetal ovary to polycystic ovary syndrome. FASEB Journal 25 2256-2265. (https:// doi.org/10.1096/fj.11-181099)

Hayes MG, Urbanek M, Ehrmann DA, Armstrong LL, Lee JY, Sisk R, Karaderi T, Barber TM, McCarthy MI, Franks S, et al. 2015 Genome-wide association of polycystic ovary syndrome implicates alterations in gonadotropin secretion in European ancestry populations. Nature Communications 6 7502. (https://doi. org/10.1038/ncomms8502)

Heijnen EM, Eijkemans MJ, Hughes EG, Laven JS, Macklon NS \& Fauser BC 2006 A meta-analysis of outcomes of conventional IVF in women with polycystic ovary syndrome. Human Reproduction Update 12 13-21. (https://doi.org/10.1093/humupd/dmi036)

Hernandez ER, Resnick CE, Holtzclaw WD, Payne DW \& Adashi EY 1988 Insulin as a regulator of androgen biosynthesis by cultured rat ovarian cells: cellular mechanism(s) underlying physiological and pharmacological hormonal actions. Endocrinology 122 2034-2043. (https://doi.org/10.1210/endo-122-5-2034)

Hickey TE, Legro RS \& Norman RJ 2006 Epigenetic modification of the $\mathrm{X}$ chromosome influences susceptibility to polycystic ovary syndrome. Journal of Clinical Endocrinology and Metabolism 91 2789-2791. (https://doi.org/10.1210/jc.2006-0069)

Hogeveen KN, Cousin P, Pugeat M, Dewailly D, Soudan B \& Hammond GL 2002 Human sex hormone-binding globulin variants associated with hyperandrogenism and ovarian dysfunction. Journal of Clinical Investigation 109 973-981. (https://doi.org/10.1172/ JCI0214060)

Holly JM, Eden JA, Alaghband-Zadeh J, Carter GD, Jemmott RC, Cianfarani S, Chard T \& Wass JA 1990 Insulin-like growth factor binding proteins in follicular fluid from normal dominant and cohort follicles, polycystic and multicystic ovaries. Clinical Endocrinology 33 53-64. (https://doi.org/10.1111/j.1365-2265.1990. tb00465.x)

Homburg R \& Amsterdam A 1998 Polysystic ovary syndrome - loss of the apoptotic mechanism in the ovarian follicles? Journal of Endocrinological Investigation 21 552-557. (https://doi.org/10.1007/ BF03350780)

Hsieh M, Zamah AM \& Conti M 2009 Epidermal growth factor-like growth factors in the follicular fluid: role in oocyte development and maturation. Seminars in Reproductive Medicine 27 52-61. (https://doi. org/10.1055/s-0028-1108010)

Huber-Buchholz MM, Carey DG \& Norman RJ 1999 Restoration of reproductive potential by lifestyle modification in obese polycystic ovary syndrome: role of insulin sensitivity and luteinizing hormone.
(C) 2019 Society for Endocrinology Published by Bioscientifica Ltd. Printed in Great Britain 
Journal of Clinical Endocrinology and Metabolism 84 1470-1474. (https://doi.org/10.1210/jcem.84.4.5596)

Hughesdon PE 1982 Morphology and morphogenesis of the SteinLeventhal ovary and of so-called 'hyperthecosis'. Obstetrical and Gynecological Survey 37 59-77. (https://doi.org/10.1097/00006254198202000-00001)

Hunter RG, Gagnidze K, McEwen BS \& Pfaff DW 2015 Stress and the dynamic genome: steroids, epigenetics, and the transposome. PNAS 112 6828-6833. (https://doi.org/10.1073/ pnas.1411260111)

Hussein MR 2005 Apoptosis in the ovary: molecular mechanisms. Human Reproduction Update 11 162-177. (https://doi.org/10.1093/ humupd/dmi001)

Hussein TS, Thompson JG \& Gilchrist RB 2006 Oocyte-secreted factors enhance oocyte developmental competence. Developmental Biology 296 514-521. (https://doi.org/10.1016/j.ydbio.2006.06.026)

Jayasena CN \& Franks S 2014 The management of patients with polycystic ovary syndrome. Nature Reviews Endocrinology 10 624-636. (https://doi.org/10.1038/nrendo.2014.102)

Johnstone E, Shelly W, Mellon S \& Cedars M 2008 Brain-derived neurotrophic factor is elevated in follicular fluid of women with PCOS. Fertility and Sterility 90 S256. (https://doi.org/10.1016/j. fertnstert.2008.07.1277)

Jonard S \& Dewailly D 2004 The follicular excess in polycystic ovaries, due to intra-ovarian hyperandrogenism, may be the main culprit for the follicular arrest. Human Reproduction Update 10 107-117. (https:// doi.org/10.1093/humupd/dmh010)

Jones MR, Brower MA, Xu N, Cui J, Mengesha E, Chen YD, Taylor KD, Azziz R \& Goodarzi MO 2015 Systems genetics reveals the functional context of PCOS loci and identifies genetic and molecular mechanisms of disease heterogeneity. PLoS Genetics 11 e1005455. (https://doi.org/10.1371/journal.pgen.1005455)

Jordan CD, Bohling SD, Charbonneau NL \& Sakai LY 2010 Fibrillins in adult human ovary and polycystic ovary syndrome: is fibrillin-3 affected in PCOS? Journal of Histochemistry and Cytochemistry $\mathbf{5 8}$ 903-915. (https://doi.org/10.1369/jhc.2010.956615)

Joseph-Horne R, Mason H, Batty S, White D, Hillier S, Urquhart M \& Franks S 2002 Luteal phase progesterone excretion in ovulatory women with polycystic ovaries. Human Reproduction 17 1459-1463. (https://doi.org/10.1093/humrep/17.6.1459)

Kandaraki E, Chatzigeorgiou A, Livadas S, Palioura E, Economou F, Koutsilieris M, Palimeri S, Panidis D \& Diamanti-Kandarakis E 2011 Endocrine disruptors and polycystic ovary syndrome (PCOS): elevated serum levels of bisphenol A in women with PCOS. Journal of Clinical Endocrinology and Metabolism 96 E480-E484. (https://doi. org/10.1210/jc.2010-1658)

Kawamura K, Kawamura N, Mulders SM, Sollewijn Gelpke MD \& Hsueh AJ 2005 Ovarian brain-derived neurotrophic factor (BDNF) promotes the development of oocytes into preimplantation embryos. PNAS 102 9206-9211. (https://doi.org/10.1073/pnas.0502442102)

Kim JK, Samaranayake M \& Pradhan S 2009 Epigenetic mechanisms in mammals. Cellular and Molecular Life Sciences 66 596-612. (https:// doi.org/10.1007/s00018-008-8432-4)

Knight PG, Satchell L \& Glister C 2012 Intra-ovarian roles of activins and inhibins. Molecular and Cellular Endocrinology 359 53-65. (https://doi.org/10.1016/j.mce.2011.04.024)

Kuijper EA, Vink JM, Lambalk CB \& Boomsma DI 2009 Prevalence of polycystic ovary syndrome in women from opposite-sex twin pairs. Journal of Clinical Endocrinology and Metabolism 94 1987-1990. (https://doi.org/10.1210/jc.2009-0191)

Kwintkiewicz J \& Giudice LC 2009 The interplay of insulin-like growth factors, gonadotropins, and endocrine disruptors in ovarian follicular development and function. Seminars in Reproductive Medicine 27 43-51. (https://doi.org/10.1055/s-0028-1108009)

Lahav-Baratz S, Kraiem Z, Shiloh H, Koifman M, Ishai D \& Dirnfeld M 2003 Decreased expression of tissue inhibitor of matrix metalloproteinases in follicular fluid from women with polycystic ovaries compared with normally ovulating patients undergoing in vitro fertilization. Fertility and Sterility 79 567-571. (https://doi. org/10.1016/S0015-0282(02)04838-0)

Lebbe M \& Woodruff TK 2013 Involvement of androgens in ovarian health and disease. Molecular Human Reproduction 19 828-837. (https://doi.org/10.1093/molehr/gat065)

Ledee-Bataille N, Lapree-Delage G, Taupin JL, Dubanchet S, Taieb J, Moreau JF \& Chaouat G 2001 Follicular fluid concentration of leukaemia inhibitory factor is decreased among women with polycystic ovarian syndrome during assisted reproduction cycles. Human Reproduction 16 2073-2078. (https://doi.org/10.1093/ humrep/16.10.2073)

Legro RS 2016 Ovulation induction in polycystic ovary syndrome: current options. Best Practice and Research Clinical Obstetrics and Gynaecology 37 152-159. (https://doi.org/10.1016/j. bpobgyn.2016.08.001)

Legro RS, Driscoll D, Strauss JF 3rd, Fox J \& Dunaif A $1998 a$ Evidence for a genetic basis for hyperandrogenemia in polycystic ovary syndrome. PNAS 95 14956-14960. (https://doi.org/10.1073/ pnas.95.25.14956)

Legro RS, Spielman R, Urbanek M, Driscoll D, Strauss JF 3rd \& Dunaif A $1998 b$ Phenotype and genotype in polycystic ovary syndrome. Recent Progress in Hormone Research 53 217-256.

Legro RS, Kunselman AR \& Dunaif A 2001 Prevalence and predictors of dyslipidemia in women with polycystic ovary syndrome. American Journal of Medicine 111 607-613. (https://doi.org/10.1016/S00029343(01)00948-2)

Li S, Zhu D, Duan H \& Tan Q 2016 The epigenomics of polycystic ovarian syndrome: from pathogenesis to clinical manifestations. Gynecological Endocrinology 32 942-946. (https://doi.org/10.1080/095 13590.2016.1203409)

Louwers YV, Stolk L, Uitterlinden AG \& Laven JS 2013 Cross-ethnic meta-analysis of genetic variants for polycystic ovary syndrome. Journal of Clinical Endocrinology and Metabolism 98 E2006-E2012. (https://doi.org/10.1210/jc.2013-2495)

Luense LJ, Veiga-Lopez A, Padmanabhan V \& Christenson LK 2011 Developmental programming: gestational testosterone treatment alters fetal ovarian gene expression. Endocrinology 152 4974-4983. (https://doi.org/10.1210/en.2011-1182)

Luo H, Kimura K, Aoki M \& Hirako M 2002 Effect of vascular endothelial growth factor on maturation, fertilization and developmental competence of bovine oocytes. Journal of Veterinary Medical Science 64 803-806. (https://doi.org/10.1292/jvms.64.803)

Luque-Ramírez M, Escobar-Morreale HF 2016 Adrenal hyperandrogenism and polycystic ovary syndrome. Current Pharmaceutical Design 22 5588-5602.

Ma CH, Yan LY, Qiao J, Sha W, Li L, Chen Y \& Sun QY 2010 Effects of tumor necrosis factor-alpha on porcine oocyte meiosis progression, spindle organization, and chromosome alignment. Fertility and Sterility 93 920-926. (https://doi.org/10.1016/j. fertnstert.2009.01.131)

Maciel GA, Baracat EC, Benda JA, Markham SM, Hensinger K, Chang RJ \& Erickson GF 2004 Stockpiling of transitional and classic primary follicles in ovaries of women with polycystic ovary syndrome. Journal of Clinical Endocrinology and Metabolism 89 5321-5327. (https://doi.org/10.1210/jc.2004-0643)

Macut D, Bjekic-Macut J \& Savic-Radojevic A 2013 Dyslipidemia and oxidative stress in PCOS. Frontiers of Hormone Research 40 51-63. (https://doi.org/10.1159/000341683)

Makri E \& Tziomalos K 2017 Prevalence, etiology and management of non-alcoholic fatty liver disease in patients with polycystic ovary syndrome. Minerva Endocrinologica 42 122-131. (https://doi. org/10.23736/S0391-1977.16.02564-5)

Maliqueo M, Sir-Petermann T, Pérez V, Echiburú B, de Guevara AL, Gálvez C, Crisosto N \& Azziz R 2009 Adrenal function during
(C) 2019 Society for Endocrinology Published by Bioscientifica Ltd. Printed in Great Britain 
childhood and puberty in daughters of women with polycystic ovary syndrome. Journal of Clinical Endocrinology and Metabolism 94 3282-3288. (https://doi.org/10.1210/jc.2009-0427)

Maliqueo M, Benrick A \& Stener-Victorin E 2014 Rodent models of polycystic ovary syndrome: phenotypic presentation, pathophysiology, and the effects of different interventions. Seminars in Reproductive Medicine 32 183-193. (https://doi. org/10.1055/s-0034-1371090)

Magoffin DA \& Jakimiuk AJ 1998 Inhibin A, inhibin B and activin A concentration in follicular fluid from women with polycystic ovary syndrome. Human Reproduction 13 2693-2698. (https://doi. org/10.1093/humrep/13.10.2693)

Manikkam M, Crespi EJ, Doop DD, Herkimer C, Lee JS, Yu S, Brown MB, Foster DL \& Padmanabhan V 2004 Fetal programming: prenatal testosterone excess leads to fetal growth retardation and postnatal catch-up growth in sheep. Endocrinology 145 790-798. (https://doi. org/10.1210/en.2003-0478)

Manikkam M, Steckler TL, Welch KB, Inskeep EK \& Padmanabhan V 2006 Fetal programming: prenatal testosterone treatment leads to follicular persistence/luteal defects; partial restoration of ovarian function by cyclic progesterone treatment. Endocrinology $\mathbf{1 4 7}$ 1997-2007. (https://doi.org/10.1210/en.2005-1338)

Manikkam M, Thompson RC, Herkimer C, Welch KB, Flak J, Karsch FJ \& Padmanabhan V 2008 Developmental programming: impact of prenatal testosterone excess on pre- and postnatal gonadotropin regulation in sheep. Biology of Reproduction 78 648-660. (https://doi. org/10.1095/biolreprod.107.063347)

Manneras-Holm L, Leonhardt H, Kullberg J, Jennische E, Oden A, Holm G, Hellstrom M, Lonn L, Olivecrona G, Stener-Victorin E, et al. 2011 Adipose tissue has aberrant morphology and function in PCOS: enlarged adipocytes and low serum adiponectin, but not circulating sex steroids, are strongly associated with insulin resistance. Journal of Clinical Endocrinology and Metabolism 96 E304-E311. (https://doi. org/10.1210/jc.2010-1290)

Marquard KL, Stephens SM, Jungheim ES, Ratts VS, Odem RR, Lanzendorf S \& Moley KH 2011 Polycystic ovary syndrome and maternal obesity affect oocyte size in in vitro fertilization/ intracytoplasmic sperm injection cycles. Fertility and Sterility $\mathbf{9 5}$ 2146.e2141-2149.e2141. (https://doi.org/10.1016/j. fertnstert.2010.10.026)

Marshall JC \& Eagleson CA 1999 Neuroendocrine aspects of polycystic ovary syndrome. Endocrinology Metabolism Clinics of North America 28 295-324. (https://doi.org/10.1016/S0889-8529(05)70071-2)

Mastorakos G, Scopa CD, Vryonidou A, Friedman TC, Kattis D, Phenekos C, Merino MJ \& Chrousos GP 1994 Presence of immunoreactive corticotropin-releasing hormone in normal and polycystic human ovaries. Journal of Clinical Endocrinology and Metabolism 79 1191-1197. (https://doi.org/10.1210/ jcem.79.4.7525629)

Mazerbourg S, Bondy CA, Zhou J \& Monget P 2003 The insulin-like growth factor system: a key determinant role in the growth and selection of ovarian follicles? A comparative species study. Reproduction in Domestic Animals 38 247-258. (https://doi. org/10.1046/j.1439-0531.2003.00440.x)

McAllister JM, Modi B, Miller BA, Biegler J, Bruggeman R, Legro RS \& Strauss JF 3rd 2014 Overexpression of a DENND1A isoform produces a polycystic ovary syndrome theca phenotype. PNAS $\mathbf{1 1 1}$ E1519-E1527. (https://doi.org/10.1073/pnas.1400574111)

McCartney CR, Eagleson CA \& Marshall JC 2002 Regulation of gonadotropin secretion: implications for polycystic ovary syndrome. Seminars in Reproductive Medicine 20 317-326. (https://doi. org/10.1055/s-2002-36706)

Melo AS, Vieira CS, Barbieri MA, Rosa ESAC, Silva AA, Cardoso VC, Reis RM, Ferriani RA, Silva-de-Sa MF \& Bettiol H 2010 High prevalence of polycystic ovary syndrome in women born small for gestational age. Human Reproduction 25 2124-2131. (https://doi. org/10.1093/humrep/deq162)

Merkin SS, Phy JL, Sites CK \& Yang D 2016 Environmental determinants of polycystic ovary syndrome. Fertility and Sterility 106 16-24. (https://doi.org/10.1016/j.fertnstert.2016.05.011)

Merz CN, Shaw LJ, Azziz R, Stanczyk FZ, Sopko G, Braunstein GD, Kelsey SF, Kip KE, Cooper-DeHoff RM, Johnson BD, et al. 2016 Cardiovascular disease and 10-year mortality in postmenopausal women with clinical features of polycystic ovary syndrome. Journal of Women's Health 25 875-881. (https://doi.org/10.1089/ jwh.2015.5441)

Mikaeili S, Rashidi BH, Safa M, Najafi A, Sobhani A, Asadi E \& Abbasi M 2016 Altered FoxO3 expression and apoptosis in granulosa cells of women with polycystic ovary syndrome. Archives of Gynecology and Obstetrics 294 185-192. (https://doi.org/10.1007/s00404-016-4068-z)

Modi BP 2016 Genetic and Epigenetic Mechanisms of Complex Reproductive Disorders. Richmond, VA: Virginia Commonwealth University.

Moore AM, Prescott M, Marshall CJ, Yip SH \& Campbell RE 2015 Enhancement of a robust arcuate GABAergic input to gonadotropinreleasing hormone neurons in a model of polycystic ovarian syndrome. PNAS 112 596-601. (https://doi.org/10.1073/ pnas.1415038112)

Moran C, Reyna R, Boots LS \& Azziz R 2005 Adrenocortical hyperresponsiveness to corticotropin in polycystic ovary syndrome patients with adrenal androgen excess. Fertility and Sterility $\mathbf{8 1}$ 126-131. (https://doi.org/10.1016/j.fertnstert.2003.07.008)

Moran LJ, Norman RJ \& Teede HJ 2015 Metabolic risk in PCOS: phenotype and adiposity impact. Trends in Endocrinology and Metabolism 26 136-143. (https://doi.org/10.1016/j.tem.2014.12.003)

Morishima A, Grumbach MM, Simpson ER, Fisher C \& Qin K 1995 Aromatase deficiency in male and female siblings caused by a novel mutation and the physiological role of estrogens. Journal of Clinical Endocrinology and Metabolism 80 3689-3698. ( https://doi. org/10.1210/jcem.80.12.8530621)

Mossa F, Carter F, Walsh SW, Kenny DA, Smith GW, Ireland JL, Hildebrandt TB, Lonergan P, Ireland JJ \& Evans AC 2013 Maternal undernutrition in cows impairs ovarian and cardiovascular systems in their offspring. Biology of Reproduction 88 92. (https://doi. org/10.1095/biolreprod.112.107235)

Mumm H, Kamper-Jorgensen M, Nybo Andersen AM, Glintborg D \& Andersen M 2013 Birth weight and polycystic ovary syndrome in adult life: a register-based study on 523,757 Danish women born 1973-1991. Fertility and Sterility 99 777-782. (https://doi. org/10.1016/j.fertnstert.2012.11.004)

Naderpoor N, Shorakae S, Joham A, Boyle J, De Courten B \& Teede HJ 2015 Obesity and polycystic ovary syndrome. Minerva Endocrinologica 40 37-51.

Nahum R, Thong KJ \& Hillier SG 1995 Metabolic regulation of androgen production by human thecal cells in vitro. Human Reproduction $\mathbf{1 0}$ 75-81. (https://doi.org/10.1093/humrep/10.1.75)

Naji M, Aleyasin A, Nekoonam S, Arefian E, Mahdian R \& Amidi F 2017 Differential Expression of miR-93 and miR-21 in granulosa cells and follicular fluid of polycystic ovary syndrome associating with different phenotypes. Scientific Reports 7 14671. (https://doi. org/10.1038/s41598-017-13250-1)

Naji M, Nekoonam S, Aleyasin A, Arefian E, Mahdian R, Azizi E, Shabani Nashtaei M \& Amidi F 2018 Expression of miR-15a, miR-145, and miR-182 in granulosa-lutein cells, follicular fluid, and serum of women with polycystic ovary syndrome (PCOS). Archives of Gynecology and Obstetrics 297 221-231. (https://doi.org/10.1007/ s00404-017-4570-y)

National Institutes of Health 2012 Evidence-based methodology workshop on polycystic ovary syndrome - final panel report. (https://prevention.nih.gov/docs/programs/pcos/FinalReport.pdf) Date Accessed 07/06/2018
(C) 2019 Society for Endocrinology Published by Bioscientifica Ltd. Printed in Great Britain 
Nelson JW, Scammell MK, Hatch EE \& Webster TF 2012 Social disparities in exposures to bisphenol A and polyfluoroalkyl chemicals: a crosssectional study within NHANES 2003-2006. Environmental Health 11 10. (https://doi.org/10.1186/1476-069X-11-10)

Nestler JE, Powers LP, Matt DW, Steingold KA, Plymate SR, Rittmaster RS, Clore JN \& Blackard WG 1991 A direct effect of hyperinsulinemia on serum sex hormone-binding globulin levels in obese women with the polycystic ovary syndrome. Journal of Clinical Endocrinology and Metabolism 72 83-89. (https://doi.org/10.1210/jcem-72-1-83)

Nielsen ME, Rasmussen IA, Kristensen SG, Christensen ST, Mollgard K, Wreford Andersen E, Byskov AG \& Yding Andersen C 2011 In human granulosa cells from small antral follicles, androgen receptor mRNA and androgen levels in follicular fluid correlate with FSH receptor mRNA. Molecular Human Reproduction 17 63-70. (https://doi. org/10.1093/molehr/gaq073)

Norman RJ, Milner CR, Groome NP \& Robertson DM 2001 Circulating follistatin concentrations are higher and activin concentrations are lower in polycystic ovarian syndrome. Human Reproduction 16 668-672. (https://doi.org/10.1093/humrep/16.4.668)

Onalan G, Selam B, Baran Y, Cincik M, Onalan R, Gunduz U, Ural AU \& Pabuccu R 2005 Serum and follicular fluid levels of soluble Fas, soluble Fas ligand and apoptosis of luteinized granulosa cells in PCOS patients undergoing IVF. Human Reproduction 20 2391-2395. (https://doi.org/10.1093/humrep/dei068)

Ortega HH, Salvetti NR \& Padmanabhan V 2009 Developmental programming: prenatal androgen excess disrupts ovarian steroid receptor balance. Reproduction 137 865-877. (https://doi.org/10.1530/ REP-08-0491)

Ortega HH, Veiga-Lopez A, Sreedharan S, del Lujan Velazquez MM, Salvetti NR \& Padmanabhan V 2015 Developmental programming: does prenatal steroid excess disrupt the ovarian VEGF system in sheep? Biology of Reproduction 93 58. (https://doi.org/10.1095/ biolreprod.115.135400)

Padmanabhan V \& Veiga-Lopez A 2013 Sheep models of polycystic ovary syndrome phenotype. Molecular and Cellular Endocrinology $\mathbf{3 7 3}$ 8-20. (https://doi.org/10.1016/j.mce.2012.10.005)

Padmanabhan V \& Veiga-Lopez A 2014 Reproduction symposium: developmental programming of reproductive and metabolic health. Journal of Animal Science 92 3199-3210. (https://doi.org/10.2527/ jas.2014-7637)

Padmanabhan V, Veiga-Lopez A, Abbott D, Recabarren S \& Herkimer C 2010 Developmental programming: impact of prenatal testosterone excess and postnatal weight gain on insulin sensitivity index and transfer of traits to offspring of overweight females. Endocrinology 151 595-605. (https://doi.org/10.1210/en.2009-1015)

Pagan YL, Srouji SS, Jimenez Y, Emerson A, Gill S \& Hall JE 2006 Inverse relationship between luteinizing hormone and body mass index in polycystic ovarian syndrome: investigation of hypothalamic and pituitary contributions. Journal of Clinical Endocrinology and Metabolism 91 1309-1316. (https://doi.org/10.1210/jc.2005-2099)

Palin MF, Bordignon VV \& Murphy BD 2012 Adiponectin and the control of female reproductive functions. Vitamins and Hormones 90 239-287. (https://doi.org/10.1016/B978-0-12-398313-8.00010-5)

Palomba S, Marotta R, Di Cello A, Russo T, Falbo A, Orio F, Tolino A, Zullo F, Esposito R \& La Sala GB 2012 Pervasive developmental disorders in children of hyperandrogenic women with polycystic ovary syndrome: a longitudinal case-control study. Clinical Endocrinology 77 898-904. (https://doi. org/10.1111/j.1365-2265.2012.04443.x)

Pastor CL, Griffin-Korf ML, Aloi JA, Evans WS \& Marshall JC 1998 Polycystic ovary syndrome: evidence for reduced sensitivity of the gonadotropin-releasing hormone pulse generator to inhibition by estradiol and progesterone. Journal of Clinical Endocrinology and Metabolism 83 582-590. (https://doi.org/10.1210/jcem.83.2.4604)

Peretz J, Vrooman L, Ricke WA, Hunt PA, Ehrlich S, Hauser R, Padmanabhan V, Taylor HS, Swan SH, VandeVoort CA, et al. 2014
Bisphenol a and reproductive health: update of experimental and human evidence, 2007-2013. Environmental Health Perspectives 122 775-786. (https://dx.doi.org/10.1289\%2Fehp.1307728)

Pru JK \& Tilly JL 2001 Programmed cell death in the ovary: insights and future prospects using genetic technologies. Molecular Endocrinology 15 845-853. (https://doi.org/10.1210/mend.15.6.0646)

Puttabyatappa M, Andriessen V, Mesquitta M, Zeng L, Pennathur S \& Padmanabhan V 2017a Developmental programming: impact of gestational steroid and metabolic milieus on mediators of insulin sensitivity in prenatal testosterone-treated female sheep. Endocrinology 158 2783-2798. (https://doi.org/10.1210/en.2017-00460)

Puttabyatappa M, Burns A, Martin JD, Mesquita M, Veiga-Lopez A \& Padmanabhan V 2017b Developmental programming: gestational exposure to excess testosterone alters expression of ovarian matrix metalloproteases and their target proteins. Reproductive Science $\mathbf{2 5}$ 882-892. (https://doi.org/10.1177/1933719117697127)

Qiao J \& Feng HL 2011 Extra- and intra-ovarian factors in polycystic ovary syndrome: impact on oocyte maturation and embryo developmental competence. Human Reproduction Update 17 17-33. (https://doi.org/10.1093/humupd/dmq032)

Qiao GY, Dong BW, Zhu CJ, Yan CY \& Chen BL 2017 Deregulation of WNT2/FZD3/ $\beta$-catenin pathway compromises the estrogen synthesis in cumulus cells from patients with polycystic ovary syndrome. Biochemical and Biophysical Research Communications 493 847-854. (https://doi.org/10.1016/j.bbrc.2017.07.057)

Qin JZ, Pang LH, Li MJ, Fan XJ, Huang RD \& Chen HY 2013 Obstetric complications in women with polycystic ovary syndrome: a systematic review and meta-analysis. Reproductive Biology and Endocrinology 11 56. (https://doi.org/10.1186/1477-7827-11-56)

Recabarren SE, Padmanabhan V, Codner E, Lobos A, Durán C, Vidal M, Foster DL \& Sir-Petermann T 2005 Postnatal developmental consequences of altered insulin sensitivity in female sheep treated prenatally with testosterone. American Journal of Physiology: Endocrinology and Metabolism 289 E801-E806. (https://doi. org/10.1152/ajpendo.00107.2005)

Recabarren SE, Rojas-Garcia PP, Recabarren MP, Alfaro VH, Smith R, Padmanabhan V \& Sir-Petermann T 2008 Prenatal testosterone excess reduces sperm count and motility. Endocrinology 149 6444-6448. (https://doi.org/10.1210/en.2008-0785)

Reddy P, Liu L, Adhikari D, Jagarlamudi K, Rajareddy S, Shen Y, Du C, Tang W, Hamalainen T, Peng SL, et al. 2008 Oocyte-specific deletion of Pten causes premature activation of the primordial follicle pool. Science 319 611-613. (https://doi.org/10.1126/science.1152257)

Risma KA, Clay CM, Nett TM, Wagner T, Yun J \& Nilson JH 1995 Targeted overexpression of luteinizing hormone in transgenic mice leads to infertility, polycystic ovaries, and ovarian tumors. PNAS 92 1322-1326. (https://doi.org/10.1073/pnas.92.5.1322)

Robinson JE, Forsdike RA \& Taylor JA 1999 In utero exposure of female lambs to testosterone reduces the sensitivity of the gonadotropinreleasing hormone neuronal network to inhibition by progesterone. Endocrinology 140 5797-5805. (https://doi.org/10.1210/ endo.140.12.7205)

Rodin A, Thakkar H, Taylor N \& Clayton R 1994 Hyperandrogenism in polycystic ovary syndrome. Evidence of dysregulation of 11 betahydroxysteroid dehydrogenase. New England Journal of Medicine 330 460-465. (https://doi.org/10.1056/NEJM199402173300703)

Rojas-Garcia PP, Recabarren MP, Sarabia L, Schon J, Gabler C, Einspanier R, Maliqueo M, Sir-Petermann T, Rey R \& Recabarren SE 2010 Prenatal testosterone excess alters Sertoli and germ cell number and testicular FSH receptor expression in rams. American Journal of Physiology: Endocrinology and Metabolism 299 E998-E1005. (https:// doi.org/10.1152/ajpendo.00032.2010)

Roland AV, Nunemaker CS, Keller SR \& Moenter SM 2010 Prenatal androgen exposure programs metabolic dysfunction in female mice. Journal of Endocrinology 207 213-223. (https://doi.org/10.1677/JOE10-0217) 
Rosmond R 2005 Role of stress in the pathogenesis of the metabolic syndrome. Psychoneuroendocrinology 30 1-10. (https://doi. org/10.1016/j.psyneuen.2004.05.007)

Rutkowska A \& Rachon D 2014 Bisphenol A (BPA) and its potential role in the pathogenesis of the polycystic ovary syndrome (PCOS). Gynecological Endocrinology 30 260-265. (https://doi.org/10.3109/095 13590.2013.871517)

Salvetti NR, Ortega HH, Veiga-Lopez A \& Padmanabhan V 2012 Developmental programming: impact of prenatal testosterone excess on ovarian cell proliferation and apoptotic factors in sheep. Biology of Reproduction 87 22, 21-10. (https://doi.org/10.1093/biolreprod/87.s1.21)

Sarma HN, Manikkam M, Herkimer C, Dell'Orco J, Welch KB, Foster DL \& Padmanabhan V 2005 Fetal programming: excess prenatal testosterone reduces postnatal luteinizing hormone, but not folliclestimulating hormone responsiveness, to estradiol negative feedback in the female. Endocrinology 146 4281-4291. (https://doi. org/10.1210/en.2005-0322)

Savabieasfahani M, Kannan K, Astapova O, Evans NP \& Padmanabhan V 2006 Developmental programming: differential effects of prenatal exposure to bisphenol-A or methoxychlor on reproductive function. Endocrinology 147 5956-5966. (https://doi.org/10.1210/en.2006-0805)

Savchev SI, Moragianni VA, Senger D, Penzias AS, Thornton K \& Usheva A 2010 Follicular fluid-specific distribution of vascular endothelial growth factor isoforms and sFlt-1 in patients undergoing IVF and their correlation with treatment outcomes. Reproductive Science 17 10361042. (https://doi.org/10.1177/1933719110376980)

Sermondade N, Dupont C, Massart P, Cedrin-Durnerin I, Levy R \& Sifer C 2013 Impact of polycystic ovary syndrome on oocyte and embryo quality. Gynecologie, Obstetrique and Fertilite 41 27-30. (https://doi.org/10.1016/j.gyobfe.2012.11.003)

Shalev E, Goldman S \& Ben-Shlomo I 2001 The balance between MMP-9 and MMP-2 and their tissue inhibitor (TIMP)-1 in luteinized granulosa cells: comparison between women with PCOS and normal ovulatory women. Molecular Human Reproduction 7 325-331. (https:// doi.org/10.1093/molehr/7.4.325)

Sharma TP, Herkimer C, West C, Ye W, Birch R, Robinson JE, Foster DL \& Padmanabhan V 2002 Fetal programming: prenatal androgen disrupts positive feedback actions of estradiol but does not affect timing of puberty in female sheep. Biology of Reproduction $\mathbf{6 6}$ 924-933. (https://doi.org/10.1095/biolreprod66.4.924)

Sir-Petermann T, Codner E, Perez V, Echiburu B, Maliqueo M, Ladron de Guevara A, Preisler J, Crisosto N, Sanchez F, Cassorla F, et al. 2009 Metabolic and reproductive features before and during puberty in daughters of women with polycystic ovary syndrome. Journal of Clinical Endocrinology and Metabolism 94 1923-1930. (https://doi. org/10.1210/jc.2008-2836)

Skinner MK 2005 Regulation of primordial follicle assembly and development. Human Reproduction Update 11 461-471. (https://doi. org/10.1093/humupd/dmi020)

Smith P, Steckler TL, Veiga-Lopez A \& Padmanabhan V 2009 Developmental programming: differential effects of prenatal testosterone and dihydrotestosterone on follicular recruitment, depletion of follicular reserve, and ovarian morphology in sheep. Biology of Reproduction 80 726-736. (https://doi.org/10.1095/ biolreprod.108.072801)

Steckler T, Wang J, Bartol FF, Roy SK \& Padmanabhan V 2005 Fetal programming: prenatal testosterone treatment causes intrauterine growth retardation, reduces ovarian reserve and increases ovarian follicular recruitment. Endocrinology 146 3185-3193. (https://doi. org/10.1210/en.2004-1444)

Steckler T, Roberts E, Doop D, Lee T \& Padmanabhan V 2007 Developmental programming in sheep: administration of testosterone during 60-90 days of pregnancy reduces breeding success and pregnancy outcome. Theriogenology 67 459-467. (https:// doi.org/10.1016/j.theriogenology.2006.08.010)
Steckler TL, Lee JS, Ye W, Inskeep EK \& Padmanabhan V 2008 Developmental programming: exogenous gonadotropin treatment rescues ovulatory function but does not completely normalize ovarian function in sheep treated prenatally with testosterone. Biology of Reproduction 79 686-695. (https://doi.org/10.1095/ biolreprod.108.068643)

Steckler TL, Herkimer C, Dumesic DA \& Padmanabhan V 2009 Developmental programming: excess weight gain amplifies the effects of prenatal testosterone excess on reproductive cyclicity implication for polycystic ovary syndrome. Endocrinology 150 1456-1465. (https://doi.org/10.1210/en.2008-1256)

Stein IF \& Leventhal ML 1935 Amenorrhea associated with bilateral polycystic ovaries. American Journal of Obstetrics and Gynecology 29 181-191. (https://doi.org/10.1016/S0002-9378(15)30642-6)

Stubbs SA, Hardy K, Da Silva-Buttkus P, Stark J, Webber LJ, Flanagan AM, Themmen AP, Visser JA, Groome NP \& Franks S 2005 Anti-mullerian hormone protein expression is reduced during the initial stages of follicle development in human polycystic ovaries. Journal of Clinical Endocrinology and Metabolism 90 5536-5543. (https://doi. org/10.1210/jc.2005-0907)

Tang WY \& Ho SM 2007 Epigenetic reprogramming and imprinting in origins of disease. Reviews in Endocrine and Metabolic Disorders 8 173-182. (https://doi.org/10.1007/s11154-007-9042-4)

Taylor AE, McCourt B, Martin KA, Anderson EJ, Adams JM, Schoenfeld D \& Hall JE 1997 Determinants of abnormal gonadotropin secretion in clinically defined women with polycystic ovary syndrome. Journal of Clinical Endocrinology and Metabolism 82 2248-2256. (https://doi. org/10.1210/jcem.82.7.4105)

Teede H, Deeks A \& Moran L 2010 Polycystic ovary syndrome: a complex condition with psychological, reproductive and metabolic manifestations that impacts on health across the lifespan. BMC Medicine 8 41. (https://doi.org/10.1186/1741-7015-8-41)

Teissier MP, Chable H, Paulhac S \& Aubard Y 2000 Comparison of follicle steroidogenesis from normal and polycystic ovaries in women undergoing IVF: relationship between steroid concentrations, follicle size, oocyte quality and fecundability. Human Reproduction 15 2471-2477. (https://doi.org/10.1093/humrep/15.12.2471)

The Rotterdam ESHRE/ASRM-Sponsored PCOS Consensus Workshop Group 2004 Revised 2003 consensus on diagnostic criteria and long-term health risks related to polycystic ovary syndrome (PCOS). Human Reproduction 19 41-47.

Unfer V, Casini ML, Marelli G, Costabile L, Gerli S \& Di Renzo GC 2005 Different routes of progesterone administration and polycystic ovary syndrome: a review of the literature. Gynecological Endocrinology 21 119-127. (https://doi.org/10.1080/09513590500170049)

Unsworth WP, Taylor JA \& Robinson JE 2005 Prenatal programming of reproductive neuroendocrine function: the effect of prenatal androgens on the development of estrogen positive feedback and ovarian cycles in the ewe. Biology of Reproduction 72 619-627. (https://doi.org/10.1095/biolreprod.104.035691)

Urbanek M, Legro RS, Driscoll DA, Azziz R, Ehrmann DA, Norman RJ, Strauss JF 3rd, Spielman RS \& Dunaif A 1999 Thirty-seven candidate genes for polycystic ovary syndrome: strongest evidence for linkage is with follistatin. PNAS 96 8573-8578. (https://doi.org/10.1073/ pnas.96.15.8573)

Vagi SJ, Azziz-Baumgartner E, Sjodin A, Calafat AM, Dumesic D, Gonzalez L, Kato K, Silva MJ, Ye X \& Azziz R 2014 Exploring the potential association between brominated diphenyl ethers, polychlorinated biphenyls, organochlorine pesticides, perfluorinated compounds, phthalates, and bisphenol A in polycystic ovary syndrome: a case-control study. BMC Endocrine Disorders 1486. (https://doi.org/10.1186/1472-6823-14-86)

Vassilatou E 2014 Nonalcoholic fatty liver disease and polycystic ovary syndrome. World Journal of Gastroenterology 20 8351-8363. (https:// doi.org/10.3748/wjg.v20.i26.8351) 
Veiga-Lopez A, Astapova OI, Aizenberg EF, Lee JS \& Padmanabhan V 2009 Developmental programming: contribution of prenatal androgen and estrogen to estradiol feedback systems and periovulatory hormonal dynamics in sheep. Biology of Reproduction 80 718-725. (https://doi.org/10.1095/ biolreprod.108.074781)

Veiga-Lopez A, Lee JS \& Padmanabhan V 2010 Developmental programming: insulin sensitizer treatment improves reproductive function in prenatal testosterone-treated female sheep. Endocrinology 151 4007-4017. (https://doi.org/10.1210/en.20100124)

Veiga-Lopez A, Moeller J, Patel D, Ye W, Pease A, Kinns J \& Padmanabhan V 2013 Developmental programming: impact of prenatal testosterone excess on insulin sensitivity, adiposity, and free fatty acid profile in postpubertal female sheep. Endocrinology 154 1731-1742. (https://doi.org/10.1210/en.2012-2145)

Veiga-Lopez A, Ye W \& Padmanabhan V 2012 Developmental programming: prenatal testosterone excess disrupts anti-Müllerian hormone expression in preantral and antral follicles. Fertility and sterility 97 748-756. (https://doi.org/10.1016/j. fertnstert.2011.12.028)

Veiga-Lopez A, Beckett EM, Abi Salloum B, Ye W \& Padmanabhan V 2014a Developmental programming: prenatal BPA treatment disrupts timing of LH surge and ovarian follicular wave dynamics in adult sheep. Toxicology and Applied Pharmacology 279 119-128. (https://doi. org/10.1016/j.taap.2014.05.016)

Veiga-Lopez A, Wurst AK, Steckler TL, Ye W \& Padmanabhan V $2014 b$ Developmental programming: postnatal estradiol amplifies ovarian follicular defects induced by fetal exposure to excess testosterone and dihydrotestosterone in sheep. Reproductive Sciences 21 444-455. (https://doi.org/10.1177/1933719113503412)

Vermeulen A 1993 Environment, human reproduction, menopause, and andropause. Environmental Health Perspectives 101 (Supplement 2) 91-100. (https://doi.org/10.1289/ehp.93101s291)

Vink JM, Sadrzadeh S, Lambalk CB \& Boomsma DI 2006 Heritability of polycystic ovary syndrome in a Dutch twin-family study. Journal of Clinical Endocrinology and Metabolism 91 2100-2104. (https://doi. org/10.1210/jc.2005-1494)

Visser JA \& Themmen AP 2014 Role of anti-Mullerian hormone and bone morphogenetic proteins in the regulation of FSH sensitivity. Molecular and Cellular Endocrinology 382 460-465. (https://doi. org/10.1016/j.mce.2013.08.012)

Volpe A, Coukos G, D’Ambrogio G, Artini PG \& Genazzani AR 1991 Follicular fluid steroid and epidermal growth factor content, and in vitro estrogen release by granulosa-luteal cells from patients with polycystic ovaries in an IVF/ET program. European Journal of Obstetrics, Gynecology, and Reproductive Biology 42 195-199. (https:// doi.org/10.1016/0028-2243(91)90219-B)

Walters KA \& Handelsman DJ 2017 Role of androgens in the ovary. Molecular and Cellular Endocrinology 465 36-47. (https://doi. org/10.1016/j.mce.2017.06.026)

Walters KA, Allan CM \& Handelsman DJ 2012 Rodent models for human polycystic ovary syndrome. Biology of Reproduction 86149 , 1-112. (https://doi.org/10.1095/biolreprod.111.097808)

Wang Q \& Sun QY 2007 Evaluation of oocyte quality: morphological, cellular and molecular predictors. Reproduction, Fertility, and Development 19 1-12. (https://doi.org/10.1071/RD06103)

Wang F, Pan J, Liu Y, Meng Q, Lv P, Qu F, Ding GL, Klausen C, Leung PC, Chan HC, et al. 2015 Alternative splicing of the androgen receptor in polycystic ovary syndrome. PNAS $1124743-4748$. (https://doi.org/10.1073/pnas.1418216112)

Webber LJ, Stubbs S, Stark J, Trew GH, Margara R, Hardy K \& Franks S 2003 Formation and early development of follicles in the polycystic ovary. Lancet 362 1017-1021. (https://doi.org/10.1016/S01406736(03)14410-8)
Webber LJ, Stubbs SA, Stark J, Margara RA, Trew GH, Lavery SA, Hardy K \& Franks S 2007 Prolonged survival in culture of preantral follicles from polycystic ovaries. Journal of Clinical Endocrinology and Metabolism 92 1975-1978. (https://doi. org/10.1210/jc.2006-1422)

Welt CK, Taylor AE, Fox J, Messerlian GM, Adams JM \& Schneyer AL 2005 Follicular arrest in polycystic ovary syndrome is associated with deficient inhibin A and B biosynthesis. Journal of Clinical Endocrinology and Metabolism 90 5582-5587. (https://doi. org/10.1210/jc.2005-0695)

West C, Foster DL, Evans NP, Robinson J \& Padmanabhan V 2001 Intrafollicular activin availability is altered in prenatally-androgenized lambs. Molecular and Cellular Endocrinology 185 51-59. (https://doi. org/10.1016/S0303-7207(01)00632-3)

Whirledge S \& Cidlowski JA 2010 Glucocorticoids, stress, and fertility. Minerva Endocrinologica 35 109-125.

Whyte J, Alexenko A, Davis A, Ellersieck M, Fountain E \& Rosenfeld C 2007 Maternal diet composition alters serum steroid and free fatty acid concentrations and vaginal $\mathrm{pH}$ in mice. Journal of Endocrinology 192 75-81. (https://doi.org/10.1677/JOE-06-0095)

Willis D, Mason H, Gilling-Smith C \& Franks S 1996 Modulation by insulin of follicle-stimulating hormone and luteinizing hormone actions in human granulosa cells of normal and polycystic ovaries. Journal of Clinical Endocrinology and Metabolism 81 302-309. (https:// doi.org/10.1210/jcem.83.11.5232)

Willis DS, Watson H, Mason HD, Galea R, Brincat M \& Franks S 1998 Premature response to luteinizing hormone of granulosa cells from anovulatory women with polycystic ovary syndrome: relevance to mechanism of anovulation. Journal of Clinical Endocrinology and Metabolism 83 3984-3991.

Wood RI \& Foster DL 1998 Sexual differentiation of reproductive neuroendocrine function in sheep. Reviews of Reproduction $\mathbf{3}$ 130-140. (https://doi.org/10.1530/ror.0.0030130)

Wood JR, Dumesic DA, Abbott DH \& Strauss JF 3rd 2007 Molecular abnormalities in oocytes from women with polycystic ovary syndrome revealed by microarray analysis. Journal of Clinical Endocrinology and Metabolism 92 705-713. (https://doi.org/10.1210/ jc.2006-2123)

Wu Y, Zhong G, Chen S, Zheng C, Liao D \& Xie M 2017 Polycystic ovary syndrome is associated with anogenital distance, a marker of prenatal androgen exposure. Human Reproduction 32 937-943. (https://doi.org/10.1093/humrep/dex042)

Xia Y, Shen S, Zhang X, Deng Z, Xiang Z, Wang H, Yi L, Gao Q \& Wang Y 2015 Epigenetic pattern changes in prenatal female Sprague-Dawley rats following exposure to androgen. Reproduction, Fertility and Development 28 1414-1423. (https://doi.org/10.1071/ RD14292)

Xiang Y, Song Y, Li Y, Zhao D, Ma L \& Tan L 2016 miR-483 is downregulated in polycystic ovarian syndrome and inhibits KGN cell proliferation via targeting Insulin-Like Growth Factor 1 (IGF1). Medical Science Monitor 22 3383-3393. (https://doi.org/10.12659/ MSM.897301)

Xu N, Kwon S, Abbott DH, Geller DH, Dumesic DA, Azziz R, Guo X \& Goodarzi MO 2011 Epigenetic mechanism underlying the development of polycystic ovary syndrome (PCOS)-like phenotypes in prenatally androgenized rhesus monkeys. PLOS ONE 6 e27286. (https://doi.org/10.1371/journal. pone.0027286)

Xu J, Xu F, Lawson MS, Tkachenko OY, Ting AY, Kahl CA, Park BS, Stouffer RR \& Bishop CV 2018 Anti-Müllerian hormone is a survival factor and promotes the growth of rhesus macaque preantral follicles during matrix-free culture. Biology of Reproduction 98 197-207. (https://doi.org/10.1093/biolre/iox181)

Xue Y, Lv J, Xu P, Gu L, Cao J, Xu L, Xue K \& Li Q 2017 Identification of microRNAs and genes associated with hyperandrogenism in the 
follicular fluid of women with polycystic ovary syndrome. Journal of Cellular Biochemistry 119 3913-3921. (https://doi.org/10.1002/ jcb.26531)

Yildizhan B, Anik Ilhan G \& Pekin T 2016 The impact of insulin resistance on clinical, hormonal and metabolic parameters in lean women with polycystic ovary syndrome. Journal of Obstetrics and Gynaecology 36 893-896. (https://doi.org/10.3109/01443615.2016.1168376)

Yildiz BO, Goodarzi MO, Guo X, Rotter JI \& Azziz R 2006 Heritability of dehydroepiandrosterone sulfate in women with polycystic ovary syndrome and their sisters. Fertility and Sterility 86 1688-1693. (https://doi.org/10.1016/j.fertnstert.2006.05.045)

Zawadzki J \& Dunaif A 1992 Current Issues in Endocrinology and Metabolism: Polycystic Ovary Syndrome. Cambridge, MA: Blackwell Scientific Publications.

Zhao SY, Qiao J, Chen YJ, Liu P, Li J \& Yan J 2010 Expression of growth differentiation factor- 9 and bone morphogenetic protein-15 in oocytes and cumulus granulosa cells of patients with polycystic ovary syndrome. Fertility and Sterility 94 261-267. (https://doi org/10.1016/j.fertnstert.2009.03.014)

Zhang CL, Wang H, Yan CY, Gao XF \& Ling XJ 2017 Deregulation of RUNX2 by miR-320a deficiency impairs steroidogenesis in cumulus granulosa cells from polycystic ovary syndrome (PCOS) patients. Biochemical and Biophysical Research Communications 482 1469-1476. (https://doi.org/10.1016/j.bbrc.2016.12.059)

Zhou R, Bird IM, Dumesic DA \& Abbott DH 2005 Adrenal hyperandrogenism is induced by fetal androgen excess in a rhesus monkey model of polycystic ovary syndrome. Journal of Clinical Endocrinology and Metabolism 90 6630-6637. (https://doi. org/10.1210/jc.2005-0691)

Zhou R, Bruns CM, Bird IM, Kemnitz JW, Goodfriend TL, Dumesic DA \& Abbott DH 2007 Pioglitazone improves insulin action and normalizes menstrual cycles in a majority of prenatally androgenized female rhesus monkeys. Reproductive Toxicology 23 438-448. (https:// doi.org/10.1016/j.reprotox.2006.12.009)

Received in final form 14 June 2018

Accepted 25 June 2018

Accepted Preprint published online 25 June 2018 